\title{
Climate risk and capital structure ${ }^{*}$
}

\author{
Edith Ginglinger \\ Université Paris-Dauphine, PSL \\ Quentin Moreau \\ Université Paris-Dauphine, PSL
}

\begin{abstract}
:
We use new data that measure forward-looking physical climate risk at the firm level to examine the impact of climate risk on capital structure. We find that greater climate risk leads to lower leverage in the post-2015 period, i.e., after the Paris Agreement. Our results hold after controlling for firm characteristics known to determine leverage, including credit ratings and several fixed effects. High climate risk firms tend to have higher loan spreads, especially for bank loans, which suggests that the reduction in debt related to climate risk is partly due to lenders becoming increasingly aware of physical climate risks.
\end{abstract}

JEL Classification: G18, G2, G32, Q54

Keywords: Climate change, Paris Agreement, capital structure, leverage, natural disasters, credit rating, cost of debt.

*Email addresses: edith.ginglinger@dauphine.psl.eu (corresponding author), quentin.moreau@ dauphine.eu. Université Paris-Dauphine, place du Marechal de Lattre, 75775 Paris cedex 16.

We thank Aymeric Bellon, Vincent Bouchet, Gilles Chemla, Hugues Chenet, Olivier Dessaint, Pascal Dumontier, Daniel Ferreira, Laurent Fresard, Thomas Heyden, Hubert de La Bruslerie, Marie-Aude Laguna, William Megginson, Jonathan Peillex, Sebastien Pouget, Manju Puri, David Robinson, conference participants at AFFI, EFMA, FEBS, Principles for Responsible Investment (PRI) academic conference, Global Alliance for Sustainable Finance and Investment (GRASFI) conference. The authors have received in-kind support from Carbone 4 for this project in the form of a dataset of climate risk ratings. We thank Florian Gallo, Jean-Marc Jancovici, Violaine Lepousez and Clément Ory for insightful discussions on the research project. 


\title{
Climate risk and capital structure
}

\begin{abstract}
:
We use new data that measure forward-looking physical climate risk at the firm level to examine the impact of climate risk on capital structure. We find that greater climate risk leads to lower leverage in the post-2015 period, i.e., after the Paris Agreement. Our results hold after controlling for firm characteristics known to determine leverage, including credit ratings and several fixed effects. High climate risk firms tend to have higher loan spreads, especially for bank loans, which suggests that the reduction in debt related to climate risk is partly due to lenders becoming increasingly aware of physical climate risks.
\end{abstract}

JEL Classification: G18, G2, G32, Q54

Keywords: Climate change, Paris Agreement, capital structure, leverage, natural disasters, credit rating, cost of debt. 


\section{Introduction}

Compared to the temperature in preindustrial times, the world has warmed by $1{ }^{\circ} \mathrm{C}$ on average. Global temperatures are still trending upward, with an increase of 2 to $4^{\circ} \mathrm{C}$ expected by 2100. Climate change has dramatic effects in the forms of sea level rise and weather-related natural catastrophes, such as droughts, storms, heat waves, floods, and heavy rainfall (Stern, 2008). The consequences of climate risks for investors are difficult to assess and to hedge. ${ }^{1}$ In 2015, Mark Carney, the former chair of the Financial Stability Board (FSB), stated that investors face potentially substantial losses from climate change consequences in terms of physical risks, liability risks and transition risks, which may be an issue for financial stability. ${ }^{2}$ These climate risks may lead to a reassessment of the value of a large range of firms' assets (plants, property, and equipment) and to increased operational costs, such as relocation costs and insurance costs, resulting in lower profits and reduced repayment capacity. Several recent papers emphasize that climate risk affects the pricing of stocks, bonds and real estate (Berkman et al. 2019; Seltzer et al. 2019; Painter, 2019; and Bernstein et al. 2019).

In this paper, we use a new firm-level measure to examine whether the physical climate risks faced by a firm have an impact on its capital structure. We hypothesize that firms exposed to greater climate risk face larger expected distress costs, which in a static tradeoff framework, involves a reduction in their optimal leverage. We find strong support for the conclusion that

${ }^{1}$ See, for example, Andersson, Bolton, and Samama (2016a and 2016b), Daniel, Litterman, and Wagner (2016), Hansen, Brock, and Barnett (2018) and Engle et al. (2019).

${ }^{2}$ Carney also underlined an urgent need for standard measures and disclosure of climate risks and established an industry-led group (Task Force on Climate-related Financial Disclosure) to design and deliver these standards (Carney, 2015). Several initiatives that provide information on climate issues already existed (i.e., the Carbon Disclosure Project and the UN principles for Responsible Investment) but were fragmented and difficult to compare. See also European Commission (2018) guidelines. 
greater climate risk leads to lower leverage in the post-2015 period, i.e., after the Paris Agreement (COP21), a historic global climate deal to limit warming to $2^{\circ} \mathrm{C}$ by 2100 , which was signed by 195 countries in December 2015 and supported by a high degree of commitment from institutional investors and central banks. ${ }^{3}$

Engle et al. (2019) note that the research on climate risk needs better data to measure firm-level climate risk exposure. In this paper, we use a comprehensive measure of physical climate risk at the firm level. We rely on the "Climate Risk Impact Screening" (CRIS) methodology developed by a French company, Carbone 4, with support from several institutional investors and public agencies, including the French Development Agency (AFD) and Caisse des Dépôts et Consignations (CDC). The CRIS risk rating is a forward-looking measure that captures the increase in intensity or frequency of climate-related hazards due to climate change. The analysis uses three emissions scenarios developed by the Intergovernmental Panel on Climate Change (IPCC), namely, low, medium and high, and the two time horizons of 2050 and 2100. For each company in the MSCI World Index, climate risk grades are quantified based on climate projections from three different climate models used by the IPCC, the geographical division of activities, country-specific vulnerabilities and industry-specific vulnerabilities. Seven levels of subrisks are examined, namely, three chronic hazards (an increase in average temperature, changes in rainfall patterns, and sea level rise) and four acute hazards (heat waves, rainfall extremes, droughts, and storms).

\footnotetext{
${ }^{3}$ Before 2015 and the Paris Agreement, despite trying for decades, the world failed to reach a global agreement on climate change due to coordination and free-riding problems.
} 
We begin our empirical analysis by estimating the relationship between a firm's leverage ratio and the CRIS measure of climate risk. Specifically, we regress the observed debt ratios of the firms that belong to the MSCI World Index over the period of 2010-2018 on climate risk measures for each firm in addition to several fixed effects and other control variables. We find that an increased physical climate risk reduces firms' leverage in the post-2015 period, i.e., after the Paris Agreement. We then examine the impact of subrisks on leverage and find that acute risks, the risks that lead to natural disasters (droughts, storms, heat waves, heavy rainfalls), are the main drivers of the leverage decrease. Sea level rise has also a significant negative effect on leverage. Our results are both statistically and economically significant. The patterns that we observe in our baseline tests remain after various robustness checks that involve changes in empirical specifications, variable construction methods and sampling restrictions. Including corporate social responsibility (CSR) measures and environmental performance scores in our regressions does not affect our results, which suggests that our climate risk measure is not a mere proxy of corporate social performance. Furthermore, by using the 2015 Paris Agreement as a shock to the awareness of firms, bankers and investors of climate risks, we also conduct a difference-in-differences approach to compare the leverage of high climate risk firms versus low climate risk firms before and after the Paris Agreement. Our findings remain unchanged.

However, climate risk could also be a component of the overall corporate credit risk; therefore, credit rating agencies (CRAs) should include it in their risk assessment, with credit ratings also reflecting climate risk. Rating agencies are increasingly aware of the need to incorporate the risks and opportunities associated with environmental and climate $(\mathrm{E} \& \mathrm{C})$ factors into their corporate credit ratings. For example, Standard and Poor's (S\&P) examined 9,000 updates between July 2015 and August 2017 to gage how these factors have featured in S\&P 
Global Ratings' corporate credit analysis. ${ }^{4}$ E\&C factors were an important consideration in the analysis of 717 cases and a driver for rating changes in 106 cases. Interestingly, of the examples that have an environmental or climate factor that was key to a rating change in the S\&P analysis, most are linked to physical climate risks. However, our results suggest that credit ratings do not reflect all the information related to physical climate risk. In all our tests, we control for credit ratings and find that the CRIS grades provide additional information that is not already embedded in credit ratings. We also find that our measure of climate risk does not impact credit ratings when controlling for the usual determinants of credit ratings. Recently, major CRAs have acquired extra-financial rating agencies, which leads to the reinforcement of their expertise in climate risk rating and could result in better recognition of climate risk in the future. ${ }^{5}$

In the traditional empirical capital structure literature, debt supply frictions are not observed, and the firms' characteristics are the main determinants of leverage. In this framework, the observed reduction in leverage would entirely result from firms becoming aware of their climate risks and lowering their demand for debt. In contrast, bondholders and bankers may be willing to reduce their exposure to climate risks by limiting the amount of debt that they lend to high climate risk firms or by increasing the cost of debt for these firms to cause them to reduce their use of debt. To test whether a supply effect occurs, we use loan-level data to examine interest rates charged on bank loans and bonds issues. We find that greater climate risk implies higher spreads on both bank loans and bond issues in the post-2015 period. The effect on bank loan spreads is greater than the effect on bond issue spreads. This enhanced effect on bank loans may

${ }^{4}$ See this report from S\&P Global Ratings.

${ }^{5}$ For example, in 2016, S\&P acquired Trucost, a provider of carbon and environmental data and risk analysis, and in 2019, Moody's acquired Four Twenty Seven, a provider of data related to physical climate risks, and VigeoEiris, a global leader in ESG data. 
be explained by banks having repeated interactions with the firms over time, which reduces the information asymmetry. ${ }^{6}$ More specifically, the often common location of head offices and operational units may enhance the knowledge of the risks to which a firm and its subsidiaries are exposed. Furthermore, the growing acknowledgment of climate-related issues by bank supervision authorities, especially in recent years (see, for example, Campiglio et al., 2018) and the lack of consideration of climate risk in credit ratings may also contribute to explain the greater effect of climate risk on bank loan spreads compared to bond issue spreads.

Overall, our findings suggest that the reduction in debt related to climate risk is shared between a demand effect, whereby firms lower their demand for debt, and a supply effect, whereby bankers and bondholders increase the interest rate that they charge to high climate risk firms.

Our paper contributes to several lines of research. First, this research is related to the literature on climate change and its impacts on firms and investors. The macroeconomic literature provides a great deal of evidence of global warming and extreme natural events that affect agricultural output, industrial output, energy demand, labor productivity, health, conflict, political stability and economic growth. ${ }^{7}$ Evidence on a microeconomic level gives rise to a recently growing literature. Bernstein, Gustafson and Lewis (2019) find that coastal properties exposed to projected sea level rise (SLR) sell at an approximately 7\% discount relative to otherwise similar properties. This SLR exposure discount is primarily driven by properties unlikely to be inundated for over half a century, which suggests that this discount is due to investors pricing long horizon

\footnotetext{
${ }^{6}$ On the benefits of bank lending relationships, see Rajan (1992), Petersen and Rajan (1994), and Agarwal and Hauswald (2010).

${ }^{7}$ See Dell et al. (2014) and Jones and Olken (2010).
} 
SLR costs. ${ }^{8}$ This result emphasizes how climate risk discounts asset values and potentially reduces their pledgeability, which, in turn, may be part of the explanation of the leverage reduction that we document in our study.

Several papers have attempted to understand the role of financial markets in pricing climate risks, and they have produced divergent results. A few papers have found that investors do not price climate risks, at least in the short or medium term. For example, by using the Palmer Drought Severity Index to estimate countries' vulnerability to droughts, Hong et al. (2019) show that equity markets do not anticipate the effects of predictably worsening droughts on agricultural firms until after they materialize. Another example of investors' lack of anticipation is related to the limiting of total carbon emissions, which will leave the majority of fossil fuel reserves as "stranded assets" (McGlade and Ekins, 2015). The Carbon Tracker Initiative (2013) emphasizes that listed oil, gas, and coal companies still largely invest in locating and developing new fossil fuel reserves, and Bolton and Kacperczyk (2019) even find a carbon premium. In a survey of institutional investors regarding their perceptions of climate risks, Krueger, Sautner and Starks (2019) underline that they find climate risks difficult to price and hedge. Respondents believe that equity valuations do not fully reflect the risks from climate change, although the overvaluations seem to be concentrated in certain industries. ${ }^{9}$

\footnotetext{
${ }^{8}$ On the impact of SLR on real estate, other results are less clear. For example, Baldauf, Garlappi and Yannelis (2019) find that houses projected to be underwater in "believer" neighborhoods tend to sell at a discount compared to houses in "denier" neighborhoods.

${ }^{9}$ Briere, Pouget and Ureche (2019) find that institutional investors may have different views about climate risk. By examining votes at general meetings on resolutions filed by shareholders to impose externality-related policies on corporate management, they find that universal owners (well-diversified, long-term investors, such as BlackRock and Vanguard) tend to be less supportive of resolutions on climate change than other mutual fund families.
} 
In contrast, other articles find that investors are increasingly aware of climate risk. Bansal, Kiku, and Ochoa (2016) establish that long-term temperature shifts have a significant negative effect on equity valuations, Berkman et al. (2019) use a firm-specific climate risk measure based on textual analysis and find that firm value is negatively related to climate risk, whereas Kruttli et al. (2019) observe that the uncertainty surrounding natural disasters is priced in option and stock prices. ${ }^{10}$

Second, our research also contributes to the literature on the impact of climate risks or climate events on credit risks and financial policies. Painter (2019) examines municipal bonds and finds that counties more likely to be affected by climate change pay more in underwriting fees and initial yields. Elnahas, Kim and Kim (2018) investigate the impact of natural disasters on the leverage of U.S. firms and observe that once disaster risks materialize, firms adjust their leverage. In our paper, we rely on a forward-looking climate risk measure and find that after 2015 , the risk related to climate change, even if not yet materialized, leads to a reduction in the leverage of the world's largest firms. Delis, de Greiff and Ongena (2019) use syndicated loan data and indicate that before 2015, banks did not price climate policy risk. After the Paris Agreement in December 2015, however, the risk is priced, which means that banks are aware of the climate policy issue and have started pricing the relevant risk post-2015. To measure climate risk, the authors use data on fossil fuel reserves from firms' annual reports and generate a firmyear measure of climate risk from the product of relative reserves and one of the climate change country-year indices. Our approach focuses on leverage and uses an overall assessment of climate

${ }^{10}$ Other papers examine growth and operating performance. For example, Barrot and Sauvagnat (2016) examine the impact of natural disasters on sales growth and find that disasters negatively affect both the sales growth of directly exposed firms and their largest customers. Hugon and Law (2019) and Addoum et al. (2019) observe that abnormal temperature negatively impacts firms' earnings. 
risk for all firms that belong to the MSCI World Index, not just firms with fossil fuel reserves. However, it is notable that the pricing of climate risk is effective in the post-2015 period and not before, which also converges with our result that after controlling for country-industry fixed effects, leverage is impacted only after 2015. Several other articles also find post-2015 effects. For example, Ilhan et al. (2019) show that the tail risk of polluting firms significantly increased after 2015, Monasterolo and De Angelis (2018) indicate that investors require higher risk premia for carbon-intensive industries' equity, Zerbib (2019) finds negative yield premiums for green bonds after May 2016 and Seltzer, Starks and Zhu (2019) provide evidence of a causal relation between climate regulatory risks and bond yield spreads after the 2015 Paris Agreement. Overall, there is currently a strong set of results that emphasize the tangible effects of the rising awareness of bankers and institutional investors regarding climate risks in the post 2015 period.

Third, our paper is also related to the literature that examines the impact of CSR issues on capital structure and the cost of capital. Chava (2014) relates environmental issues measured by KLD criteria (currently MSCI ESG) and the cost of equity and debt and finds that firms that cause environmental externalities (e.g., toxic waste) have higher equity and debt costs. Similarly, Chang et al. (2018) observe that firms with greater environmental liabilities maintain lower financial leverage ratios, with a lower fraction of bank debt in total debt. This result is consistent with our finding that banks seem to be more likely than bondholders to charge higher loan spreads in response to an increase in climate risk. Amiraslani et al. (2017) find that during the 2008-2009 financial crisis, high-CSR firms were able to raise more debt at lower spreads, better credit ratings and longer maturities. According to Sharfman and Fernando (2008), improved environmental risk management is associated with lower capital costs and allows for more leverage, whereas El Ghoul et al. (2011) report that firms with better CSR scores exhibit more 
inexpensive equity financing. Our results relative to the impact of climate risk on leverage and the cost of debt remain after considering CSR scores, which suggests that physical climate risk represents an additional risk besides the environmental issues that nonfinancial rating agencies usually rate.

The rest of the paper is structured as follows. In section 2, we present the institutional context of climate risk and our hypotheses. In section 3, we present our climate risk measures and our dataset. We analyze our empirical results in section 4, and section 5 concludes.

\section{Hypothesis development}

\subsection{Effect of climate risk on leverage}

Static tradeoff theory (see, for example, Fischer, Heinkel, and Zechner (1989); Leland (1994)) predicts that it is optimal for firms to borrow more when they are subject to lower debt issuance costs, higher corporate taxes, lower bankruptcy costs, a higher liquidation value of assets and lower profit volatility. A large number of empirical studies document evidence that supports static tradeoff theory and the existence of a target debt level. ${ }^{11}$

Climate risk can have an impact on the probability of failure and on the costs associated with a possible failure. Thus, the value of a firm's assets may be reduced if they are located in areas that are subject to significant climatic risks. The impairment may be related to asset destruction by an extreme climatic event. In addition, a loss in the assets' market value may result

\footnotetext{
${ }^{11}$ For example, see Titman and Wessels (1988), Rajan and Zingales (1995), Graham (1996), and Hovakimian, Opler, and Titman (2001). For a review of the empirical capital structure research, see Graham and Leary (2011).
} 
from the inability to sell these assets to an acquirer due to the increased climate risks. ${ }^{12}$ Insurance companies can partly mitigate the first type of costs but do not cover the second type.

Therefore, our first hypothesis is that firms exposed to greater climate risk face larger expected distress costs, which in a static tradeoff framework, involves a reduction in their optimal leverage.

2.2. Climate risk and leverage: is there a supply effect?

The traditional hypothesis in the empirical capital structure literature is that the observed level of debt equals the firm's demand level, which means that there is no supply friction. Firm characteristics are then the main determinants of leverage. However, there may be climate effects related to the debt supply if lenders become increasingly aware of climate risk and subject firms to more stringent regulations and disclosure requirements. The climate risk effects can occur directly through a quantity channel if lenders are willing to lend less to firms exposed to higher climate risk or indirectly through a price channel if lenders are increasing the cost of debt for high climate risk firms. To verify this last effect, we conduct empirical tests by using loan-level data, specifically, bank loans on the one hand and bond issues on the other hand. We assume that banks have better knowledge of the climate risks to which a firm is exposed due to a closer relationship with companies, the often common location of head offices and operational units, and the growing acknowledgment of climate-related issues by central banks. Therefore, our second hypothesis is that climate risk should increase the cost of debt and that this effect should be larger for bank debt than for bond issues.

\footnotetext{
${ }^{12}$ As underlined by Campello and Giambona (2013), beyond standard proxies for tangibility, the redeployability of tangible assets is a main determinant of corporate leverage.
} 
2.3. Climate risks: why is 2015 a key year for climate risk awareness?

Although the United Nations Framework Convention on Climate Change (UNFCCC), which was adopted in 1992, establishes the general legal framework for international climate change action, it was not until 1997 that countries agreed on quantified emissions limits for developed countries for the first commitment period of the Kyoto Protocol (2008-2012). However, as Andersson et al. (2016b) underline, these top-down rules imposed on businesses by governments resulted in little progress in the field of climate change mitigation. In contrast, 2015 was a pivotal year in considering climate change, as economic actors decided to take up the issue. In 2015, the FSB established the Task Force on Climate-related Financial Disclosures (TCFD) to develop recommendations for more effective climate-related disclosures that could "promote more informed investment, credit, and insurance underwriting decisions" and, in turn, "would enable stakeholders to understand better the concentrations of carbon-related assets in the financial sector and the financial system's exposures to climate-related risks." Furthermore, the Paris Agreement, which was signed in December 2015, applies for the first time to all countries, including major developing countries with large emissions, such as India and China. ${ }^{13}$ One of the core aims of the Paris Agreement was to make all financial flows consistent with a pathway towards low-emissions and climate-resilient development. The Agreement sends a strong signal that all finance, both public and private, needs to be directed towards the climate challenge. This achievement can be attributed to a new bottom-up approach centered around intended nationally determined contributions (INDCs), including all economic actors. Several initiatives have since

\footnotetext{
${ }^{13}$ On November 4, 2019, the U.S. gave a formal notice of intention to withdraw from the Paris Agreement. The formal departure will take effect on November 4, 2020.
} 
been developed to increase investors and central banks' awareness of the climate risks to which they are exposed. ${ }^{14}$ Furthermore, between 2013 and 2017, the number of subnational and national-level policy and regulatory measures has more than doubled (from 139 to 300 ), ${ }^{15}$ with a substantial rise in system-level initiatives (finance regulations and guidelines and national level roadmaps for green finance). In 2016, China adopted the "Guidelines for establishing a green financial system". In the same year, the European Union established the High-Level Expert Group on Sustainable Finance (HLEG), which led in 2018 to the European Commission's "Action Plan on Financing Sustainable Growth" including regulations on the establishment of a taxonomy to facilitate green investments not only on disclosures by institutional investors and asset managers but also on carbon-related benchmarks. Furthermore, according to its Climate Change Action Plan 2016-2020, the World Bank pledged to invest \$29 billion annually to fight against climate change, where $\$ 13$ billion comes from the private sector.

To the extent that the many recent climate change initiatives have increased investors and central banks' attention to climate risk, we assume that the effects of climate risks on capital structure will be more pronounced in the period after 2015.

${ }^{14}$ For example, the United Nations' Principles for Responsible Investment (PRI) network indicated that in June 2019, \$86.3 trillion in assets were under management with 2,372 investors (compared to \$21 trillion in assets under management and 203 signatories in 2010), the CDP (carbon disclosure project) had 525 investors for $\$ 96$ trillion in assets and climate action 100+ had 360 investors and more than \$34 trillion in assets under management (August 2019). The Network of Central Banks and Supervisors for Greening the Financial System (NGFS) was created in 2017 to enhance the role of the financial system to manage risks and to mobilize capital for green and low-carbon investments (42 central banks in 2019).

${ }^{15}$ See UN Environment (2018), “Aligning the financial system with sustainable development”. For example, in 2015, Article 173 of France's Law on Energy Transition for Green Growth established new reporting requirements for financial firms to improve the quality of climate disclosure on their investment policy. 
3. Data

\subsection{Physical climate risk measures}

To tackle the issue of better disclosure of climate risk, the FSB, on the request of G20 countries, established the TCFD in 2015. In 2017, the task force issued a set of recommendations that outlined two major categories of climate-related risk: transition risks (related to carbon and mitigation issues) and physical risks (related to impacts and adaptation issues). Several data providers (for example, RepRisk and MSCI ESG) focus on transition risk and CSR in relation to environmental externalities. However, these data providers do not provide data on the exposure of firms to the physical consequences of climate change. The assessment of climate risk at the firm level is not easy because it depends on both geographical factors and vulnerability factors specific to the firm's activity.

In this paper, we use the CRIS methodology, which was developed by the French firm Carbone 4 in cooperation with several financial institutions. ${ }^{16}$ The CRIS measures aim at assessing the climate-related physical risks that face companies and their business units in the future by breaking down the firm's activity into geographical and industrial segments and by assessing the future climate risk for each country-industry pair. Thus, rather than focusing on externalities produced at the firm level, CRIS data capture externalities incurred at the firm level. Each climate risk rating is a function of location-specific climate hazards and sector-specific vulnerabilities. Industry information comes from the GICS, ICB and NAICS codes. The geographical division of activities is based on sales, tangible assets, or a combination of both, depending on the low, high or medium capital intensity of the sector to which the company

\footnotetext{
${ }^{16}$ More information is available here.
} 
belongs. Geographical information depends on the granularity of the information disclosed by the companies. Six of the seven largest countries (Brazil, Canada, China, India, Russia, and the USA) are further divided into 4 subcountries. At its broadest level, climate risk is measured through an index that aggregates 7 hazards: 4 of these are acute (extreme) hazards, i.e., heatwaves, rainfall extremes, drought, and storms, and 3 are chronic hazards, i.e., increases in average temperature, changes in rainfall patterns and sea level rise.

The CRIS measures are split into two time horizons (2050 and 2100) and three intensity cases (low, medium, high), which reflect the Intergovernmental Panel on Climate Change (IPCC) scenarios and are formally named Representative Concentration Pathways (RCPs). ${ }^{17}$ The CRIS risk rating does not capture the absolute risk from future climate or weather but does capture the increased risk due to the increase in the intensity or frequency of the climate-related hazards in the future due to global warming compared to historical reference average hazards. Final ratings are attributed on a scale of 0 to 99 , and when the rating is higher, the risk is greater. As the rating scale is relative, a low rating does not necessarily imply low risk in absolute terms but rather means that the risk is in the lower part of the gradient in relative terms. For a company with multiple business segments (various sectors in various countries), for each hazard, the risk rating is based on the weighted arithmetic mean of all the risk ratings calculated for each of the company's business segments for this same hazard. The weighting is proportional to the breakdown of the company's revenue or fixed assets (if capital intensive) in its various segments.

\footnotetext{
${ }^{17}$ The RCPs include a stringent mitigation scenario (RCP2.6), two intermediate scenarios (RCP4.5 and RCP6.0) and one scenario with very high GHG emissions (RCP8.5). Scenarios without additional efforts to constrain emissions ("baseline scenarios") lead to pathways that range between RCP6.0 and RCP8.5. Currently, the RCP2.6 scenario feasibility is seriously in question. Therefore, the CRIS measures rely on the RCP4.5 (low), RCP6.0 (medium) and RCP8.5 (high) scenarios.
} 
For each hazard, the risk rating of a specific sector in a specific country is a combination of the hazard rating of the country and the vulnerability rating of the sector.

In this paper, for the sake of clarity, we use a unique CRIS rating that corresponds to the 2050 horizon and medium intensity risk. As our purpose is to examine the impact of climate risk on leverage, the 2050 horizon seems to be relevant: by analyzing bond issues of more than $\$ 200$ million available in Thomson-Reuters, we find that only $6.8 \%$ of the offerings have a maturity greater than 30 years and that $0.2 \%$ have a maturity over 70 years. In unreported robustness checks, we also use the 2100 horizon and low/high intensity risks, and the results are qualitatively unchanged.

The CRIS ratings cover the sphere of the MSCI World Index for 2016. As the climate risk is determined based on a 2050 horizon, we assume that this risk remains stable over the period studied (2010-2018) and that the company's activities and locations do not undergo major changes over the period. After excluding financial firms and observations with missing data (see below), we are left with 1,212 firms.

Table 1, Panel A presents the descriptive statistics for the climate risk CRIS ratings. The average overall rating is 35.161 (median $=36.994)$. The average rating for subrisks varies from 16.168 for rainfall patterns to 44.197 for storms.

\subsection{Credit ratings}

Credit ratings at the issuer level are obtained from Thomson-Reuters. This variable is based on the S\&P Long-term Issuer Rating when available. If this rating is not available, we rely on Moody's Long-term Issuer Rating, and we rely on Fitch's Long-term Issuer Default Rating if both previous measures are missing. Similar to Baghai et al. (2014), we linearize these ratings 
from 1 to 20. Investment grade ratings are coded between 11 and 20, whereas high yield ratings are coded between 1 and 10. Missing ratings are coded 0.

Of our firm-year observations, $67 \%$ are rated and therefore have potential access to public debt markets, which reflects the fact that the sample comprises the world's largest listed companies that belong to the MSCI World Index. The average credit rating is 11.7 (median 12), which corresponds to an S\&P grade of BBB.

\subsection{Financial and accounting data}

The financial and accounting data are from Compustat North America and Compustat Global. We first matched the companies covered by the CRIS grades with the data available in Compustat for fiscal years 2010 to 2017, which yields 11,836 firm-year observations. By relying on 2-digit SIC codes, we excluded SIC codes 60 to 69 , as financial firms are subject to special regulations concerning their capital structure. Missing values for long-term debt, EBIT, R\&D expenses and issuer ratings were set to zero. This assumption is noncritical, as only 71 observations have missing values of long-term debt. Missing ages were set to 1 to use the natural logarithm. We have 3 additional observations with missing EBIT. We excluded the observations with missing values of operating expenses and the observations for which we were unable to compute Tobin's Q. Therefore, we were left with 9,138 firm-year observations that cover 1,212 firms. These figures are sound as on the one hand, 1,604 firms are covered by CRIS, and on the other hand, the MSCI World Index covers approximately 1,600 firms, with $16.33 \%$ of them 
belonging to the financial sector. ${ }^{18}$ We extended our database to 2018 when the data became available. In total, our database covers 10,240 firm-year observations for 1,212 firms.

Our main measure of leverage for firm $i$ in year $t$ is a book leverage variable, which is defined as follows:

$$
\text { BookLev }_{i t}=\frac{D L T T_{i t}}{A T_{i t}}
$$

where $D L T T_{i t}$ is the amount of long-term debt that exceeds a maturity of one year, and $A T_{i t}$ is the book value of total assets. We exclude the debt in current liabilities because of the long-term nature of climate risks.

Similarly, we define the market leverage for firm $i$ in year $t$ as follows:

$$
\operatorname{MarketLev}_{i t}=\frac{D L T T_{i t}}{A T_{i t}-C E Q_{i t}+P R C C_{-} F * C S H O}
$$

if the firm is covered by Compustat North America; and

$$
\operatorname{MarketLev}_{i t}=\frac{D L T T_{i t}}{A T_{i t}-C E Q_{i t}+P R C C D * C S H O C}
$$

if the firm is covered by Compustat Global.

All the variables computed from Compustat are winsorized at the $1 \%$ level to prevent the effect of potential outliers. Country fixed effects are based on headquarter locations, and industry fixed effects are based on the 2 digit SIC codes.

In Table 1, Panel B, the means (medians) of various firm characteristics are reported for the full sample and are then disaggregated in Panel $\mathrm{C}$ between low climate risk (below the $40^{\text {th }}$ percentile) and high climate risk (above the $60^{\text {th }}$ percentile) firms. The average long-term book

\footnotetext{
${ }^{18}$ See here for details.
} 
leverage is $21.5 \%$. High climate risk firms (with an average CRIS rating of 45.3) are less leveraged (18.1\%) than low climate risk firms (with an average CRIS rating of 24.3) (23.6\%). Market leverage is also significantly lower for high versus low climate risk firms, even if the difference is smaller (13.3\% versus $15.1 \%)$. High climate risk firms are larger and have more tangible assets, more R\&D expenses and a lower Tobin's Q than low climate risk firms.

\subsection{Bank loan and bond issuance data}

We obtain bank loan data by using Dealscan and focus on loans with maturities greater than 3 years. We use the items MinBps and MaxBps as measures of the cost of the loan. As explained by Berg et al. (2016), the two items are equal to the spread if no performance pricing scheme exists. Therefore, we exclude the observations for which such a scheme exists. We also exclude the observations for which at least one of the independent variables used in our regressions is unavailable. This bank-loan level dataset is then matched with the data described in the previous sections. The correspondence between Dealscan and Compustat data is achieved with the linking database developed by Chava and Roberts (2008). Our total number of bank loan observations is 3,717. The descriptive statistics are detailed in Table 1, Panel D.

Furthermore, we extract bond issuance data from Thomson-Reuters, by focusing on vanilla, fixed-coupon bonds with an amount issued of at least \$100 million. Bessembinder et al. (2018) define small corporate bonds as those with an issue size under \$500 million. Helwege and Wang (2017) find that only $30 \%$ of the bond issuances have a size under $\$ 292$ million in 2002 dollars. For these reasons, and as our dataset covers the world's largest companies, our \$100 million cutoff seems to be appropriate. In Dealscan, interest rates charged on bank loans are expressed in terms of basis points added to a reference rate (spreads). To draw a parallel between bank loans 
and bond issuances, we match our bond data from Thomson-Reuters with the benchmark spread at issue reported in Bloomberg. To the best of our knowledge, this variable is the closest equivalent to Dealscan's spread. It is, however, important to note that the benchmark spread at issue tends to be defined over local benchmarks, whereas the spread in Dealscan is primarily defined with respect to LIBOR. As noted by Hertzel and Officer (2012), Dealscan converts nonLIBOR spreads into LIBOR-equivalents, although despite this conversion, spreads tend to be higher for loans tied to non-LIBOR rates. Our total number of bond issue observations is 4,435 . The descriptive statistics are detailed in Table 1, Panel E.

The characteristics of firms in the samples of bank borrowers and bond issuers are similar overall, even if bond issuers are larger and older than bank borrowers. The climate risk is larger for bond issuers. The average maturity is larger for bond issues (9.7 years) compared to bank loans (5.1 years).

\section{Empirical results}

\subsection{Leverage and climate risk}

The descriptive statistics show that firms with high climate risk are less highly leveraged. It may be that firms with high climate risk are also the firms that find debt less valuable. However, as these firms are larger and have more tangible assets, the theory predicts that they should demand more debt, which suggests that they are not in a situation in which they would attach less value to debt. Based on the literature of capital structure determinants, we regress the firm's leverage on a set of firm characteristics, including credit ratings and climate risk measures. 
Clustering effects could bias the statistical significance of the results because of firm leverage persistence over time. Thus, in estimating our regressions, we apply the procedures described in Petersen (2009) to adjust the standard errors for clustering by firm. Our baseline regression is as follows:

$$
\text { LTDebt }_{i t}=\alpha+\beta_{1} \text { Climate risk }_{i}+\beta_{2} X_{i t}+\beta_{3} Z_{i t}+\varepsilon_{i t}
$$

LTDebt $_{i t}$ refers to our measure of long-term debt, either BookLev $v_{i t}$ or MarketLev $v_{i t}$, Climate $_{i}$ represents the value of the overall climate change risk exposure of a firm, $X_{i t}$ is a vector of controls that have been shown to affect the level of debt holdings and $Z_{i t}$ is a vector of fixed effects. For regressions (2), (3), (5), (6) and (7) of Table 2, Climate risk is interacted with Post2015, a dummy equal to one after 2015. For these regressions, the equation is as follows:

$$
\text { LTDebt }_{i t}=\alpha+\beta_{1} \text { Climate risk }_{i}+\beta_{2} \text { Climate risk }_{i} * \text { Post } 2015+\beta_{3} X_{i t}+\beta_{4} Z_{i t}+\varepsilon_{i t}
$$

Our results confirm the previous work on capital structure. ${ }^{19}$ Firms with more tangible assets, as measured by a firm's property, plant and equipment to total asset ratio, have a higher debt ratio. In contrast, intangible assets, as measured as research and development expenses scaled by total assets, reduce a firm's leverage. More profitable firms (EBIT/total assets) and firms with a higher proportion of operational expenses are less leveraged (Table 2, Panel A). Leverage further increases with size, which confirms previous results that larger firms are less risky or incur lower issue costs. When market values are considered (Table 2, Panel B), these results remain similar. In addition, firms with higher Tobin's Q values are less leveraged, which

\footnotetext{
${ }^{19}$ For example, see Titman and Wessels (1988), Rajan and Zingales (1995), Graham, Lemmon, and Schallheim (1998), Hovakimian, Opler, and Titman (2001), and Strebulaev and Yang (2013).
} 
reflects their greater risk and potential for growth. Furthermore, by including industry dummies and year dummies, we can completely control for any determinant of leverage that is constant within a year or an industry.

Controlling for these fundamental differences between firms, as well as year and industry fixed effects, we find that increased physical climate risk reduces leverage: a 10-point increase in the overall risk rating is associated with a 3.84\% decrease in the long-term book debt ratio (Panel A, column 1) and a $1.57 \%$ decrease in the market debt ratio (Panel B, column 1). The year 2015 was a pivotal year for considering climate risk that resulted from the Paris Agreement (COP21) and the implementation of the TCFD. Therefore, we also examine whether the impact of climate risk on leverage changed after 2015 by interacting our climate risk measure with a dummy variable equal to one for the post-2015 period. We find that after 2015, a 10-point increase in climate risk reduces debt by an additional $1.24 \%$ for book value (Panel A, column 2) or $0.50 \%$ for market value (Panel B, column 2).

Our estimates have thus far ignored the location of the headquarters of the firm. It could be that our climate risk variable reflects the climate characteristics of the country in which the firm is located and other determinants of leverage that are constant within a country given its institutional and tax characteristics. We therefore further include country-industry dummies to verify that climate risk is not a proxy for a firm's headquarter location or a proxy for the interaction effect between a firm's headquarter location and the industry in which it operates; these concerns arise due to the construction methodology of the climate risk indicator. We find that until 2015, the effect of climate risk on book leverage vanishes when country-industry dummies are included in the regressions. However, after 2015, the effect is still there in both cases, which suggests that in addition to country characteristics, there is an incremental climate 
risk factor that reduces leverage by $1.21 \%$ for a 10 -point increase in climate risk when book leverage is considered (Panel A, column 3) and by $0.48 \%$ when market leverage is considered (Panel B, column 3). This effect is economically significant as it represents $5.63 \%$ of the leverage when measured in book value and $3.33 \%$ of the leverage when measured in market value.

Climate risk could also be a component of the overall corporate credit risk. Graham and Harvey (2001) find that for CFOs, credit ratings are their second highest concern when determining their capital structure. If credit ratings already reflect climate risk, adding climate risk variables would not provide any additional information to the determinants of leverage. To verify that our climate risk measure is not a mere proxy for credit risk, we add a variable that linearizes the credit ratings from 1 (D) to 20 (AAA) for firms that benefit from a rating and is zero otherwise. We find that firms with more favorable ratings have more long-term debt than firms that are poorly rated (Table 2, Panel A, columns 4 to 6, for book leverage, and Panel B, columns 4 to 6 , for market leverage). Considering credit ratings does not change our main results that leverage decreases with climate risks after $2015 .^{20}$

Our findings may also result from a reverse causality between the credit rating and leverage. To address this potential problem, we use an instrumental variables approach. In the first stage, we estimate the endogenous variable (CreditRating) as a function of the exogeneous variable in the second stage plus an additional instrument. Our credit rating variable instrument is based on its means for groups by year/sector/country. This instrument is correlated with our credit rating variable, although it is unlikely that the debt level of a given firm will depend on the average

\footnotetext{
${ }^{20}$ In unreported tests, we also introduce a dummy variable that is equal to 1 if the firm is not rated by any of the three major rating agencies of Standard and Poor's, Moody's and Fitch. Confirming previous results (Faulkender and Petersen, 2005), we find that firms without a credit rating are significantly less leveraged (-12.3\% in book leverage, and $-8.5 \%$ in market leverage). Our main results remain similar.
} 
rating of the sector for a given year and country once fixed effects are considered. Our results are confirmed, and the magnitude of the coefficients of the climate risk measure remains similar for book leverage (Table 2, Panel A, column 7). For market leverage (Table 2, Panel B, column 7), we notice that with this instrumental variable approach, the effect of climate risk vanishes, and only the effect of climate risk after 2015 remains.

These findings suggest that our CRIS climate risk measure provides an additional risk factor that has an impact on leverage after 2015 and that is not already included in the credit risk ratings. After the strong signals sent to all participants in the financial system in 2015 regarding the necessity to develop climate-related disclosures and better understand their exposure to climate-related risks, both managers and investors became more aware of climate risks, which, in turn, can explain the reduction in leverage that we observe.

In Table 3, we estimate the effect of climate risk on two subsamples. The high (low) risk subsample comprises the firms with a climate risk above (below) the $60^{\text {th }}\left(40^{\text {th }}\right)$ percentile. The results indicate that the effect of climate risk on leverage is concentrated on the firms with a high climate risk.

\subsection{Acute risks and chronic risks}

CRIS climate risk ratings combine information on the following seven direct climate hazards: three chronic hazards (increases in average temperature, changes in rainfall patterns, and sea level rise) and four acute hazards (heat waves, droughts, rainfall extremes, and storms). For each hazard, the rating is based on the analysis of information on the magnitude, duration and frequency of the hazard (particularly relevant for acute hazards). To build a rating of 0 to 99 for each climate variable and each country, the relative changes are first extracted in the future time 
horizons compared to the historic reference period and then normalized across all scenarios and time horizons. These direct hazards are associated with information on the risk-aggravating context to capture indirect hazards. For example, the impact of heavy rainfall is larger when the proportion of high slopes in the area is high because of increased landslide risks, and extreme droughts lead not only to water scarcity but also to wildfires.

We examine the impact of each of these 7 climate subrisks on the leverage of firms. In equations (1) and (2), the overall climate risk variable is replaced by subrisk measures. Since the risk variables by category are normalized, their values are of the same magnitude as the overall rating. Therefore, the regression coefficients reflect the relative impact of the risk variables on debt but not the weight of each risk in the total risk to explain the climate impact on debt.

The results in Table 4 indicate that the four acute risks have a significant negative impact on leverage over the entire period, without including country-industry fixed effects in the regressions and after 2015 when country-industry fixed effects are considered. The magnitude of the effect is comparable across subrisks. A 10-point increase in the subrisk rating is associated with a $1.98 \%$ decrease in the long-term book debt ratio for storm risks, $2.59 \%$ for heavy rain risks, $2.87 \%$ for heat wave risks and $2.91 \%$ for drought. When controlling for country-industry fixed effects, the impact is significant after 2015 , with a magnitude of $0.83 \%$ for storms, $0.92 \%$ for heat waves, and $1.18 \%$ for drought. Among chronic risks, sea level rise has an impact that is comparable to acute risks, whereas temperature rise in itself has no impact on leverage. Interestingly, we notice that chronic and extreme rainfall risks are significant in the entire sample period. Heavy rain risk has an impact of $0.85 \%$, which is supplemented by an additional $0.89 \%$ after 2015. 
These results emphasize that the impact of aggregate climate risk on leverage is primarily because of the potential increase in the risks of extreme events on the 2050 horizon.

\subsection{Climate risk and leverage: is there a supply effect?}

The observed level of debt is a function of a firm's demand for debt: in the absence of frictions, firms can borrow up to their optimum leverage, which depends on their characteristics, according to the traditional assumption in the empirical capital structure literature. However, the reduction in leverage that we observe in the post-2015 period may also be the result of supply factors. As lenders become more aware of climate risk, they could choose to lend less to firms that face high climate risk, or to increase their cost of debt which leads them to reduce their use of debt. To test whether supply factors are involved, we examine loan-level data that cover bank loans on the one hand and bond issues on the other hand. If a supply effect exists, the reluctance to finance high climate risk firms should be materialized by higher spreads.

\subsubsection{Climate risk and public debt markets}

We first focus on the impact of physical climate risks on the cost of bonds. With the logvalue of the benchmark spread at issue as our measure of the cost of borrowing, we find a post2015 rise in interest rates in bond markets. The effect is concentrated in high-risk firms. Columns (1) to (3) in Table 5 report the results for bonds with a maturity at issuance of more than 3 years, and columns (4) to (6) indicate the results on maturities of at least 5 years. When focusing on bonds that have a maturity greater than 3 years, we find that post-2015, a 10-point increase in the 
climate risk generates a 23-basis point increase in the spread at issue in the high-risk group. ${ }^{21}$ The effect is 22-basis point when focusing on maturities of at least 5 years. In both cases, we do not find any significant effect within the low-risk group, and the difference in the coefficients is significant between the two risk-subgroups. All of our specifications include fixed effects to account for the number of loans to the company on the same date, loan purpose and secured/unsecured status. We do not include fixed effects that represent the type of security (almost all of our observations are denoted by Thomson-Reuters as debenture, note or bond) for several reasons. First, we have explicitly constructed our sample such that it represents homogenous offerings, i.e., only vanilla fixed-coupon bonds. Second, the other control variables and fixed effects (notably, maturity and secured/unsecured status) should account for the remaining differences. However, our results are similar if we add this fixed effect (17 to 18 bps), which is used in the next section. We further include country, industry and year fixed effects. As the dataset is cross-sectional, some firms have just one loan in the observation period, which precludes the use of standard error clustering at the firm level. Therefore, we use a double clustering at the country-industry level. As Petersen (2009) explains, clustering or fixed effects are substitutes to address the dependence in one dimension, and we therefore do not include country-industry fixed effects in these specifications.

Our findings indicate a moderate, albeit significant, impact of physical climate risks on public debt cost in the post-2015 period.

${ }^{21}$ For each regression, we compute the marginal effects at the mean of the dependent variable. For example, the mean Log Spread on bonds with a maturity of more than 3 years issued by the high-risk group is 4.394. The marginal effect of a 10-point increase in the climate risk on spreads is therefore $\exp (4.394+10 * 0.0246)-\exp (4.394)=23 \mathrm{bps}$. 


\subsubsection{Climate risk and bank loan markets}

We find that compared to bonds and in the post-2015 period, bank loans exhibit a similar pattern but in larger magnitudes. Indeed, similar to bonds, the effect is concentrated in high-risk firms, but for these risky firms, the effect of a 10-point increase in the climate risk is 65 bps for maturities greater than 3 years (Table 6, columns (1) to (3)) and 75 bps for maturities of at least 5 years (Table 6, columns (4) to (6)) compared to 22 to 23 bps for bank loans. We do not find any significant effect within the low-risk group, and the difference in the coefficients is significant between the two risk-subgroups. As indicated in section 3.4, the spreads in Dealscan tend to be defined as LIBOR-equivalents but are higher for loans that are not contractually tied to LIBOR. In our specifications, we therefore add currency fixed effects to account for these differences to complement the fixed effects detailed in section 4.3.1.

These findings suggest that bankers may be more prone than bondholders to consider climate risk when deciding on the cost of their loans. Indeed, our results emphasize that bankers charge increased spreads for high climate risk firms that range from 65 to 75 bps compared to 22 to 23 bps for bonds. We acknowledge that due to the inherent differences in data sources, data availability and the nature of the operations studied, we can only design our tests such that they come as close as possible to a ceteris paribus analysis. Our results are consistent with banks' information-advantage and increased bank supervision explanations.

Overall our findings suggest that physical climate risks have an effect on debt supply by increasing the cost of debt for high climate risk firms. 


\subsection{Credit ratings and climate risk}

We have seen in previous tests that the climate risk rating provides additional information compared to the credit rating to explain a firm's leverage after 2015. In this paragraph, we intend to explore the relationship between credit risk and climate risk in more detail. Credit ratings are fundamentally forward-looking; they are beliefs about the downside risks that surround promised future outcomes and the probability of financial distress. CRAs thus evaluate the fundamental drivers of creditworthiness over the long term. Climate change may affect creditworthiness through potential economic impact, physical damage to assets and indirect impacts from supply chain disruption. Credit ratings should at least partially reflect climate risks, even if they do not consider them in their entirety. Rating agencies are multiplying the announcements related to environmental and climate risk factors, with a primary focus on sovereign and municipal bonds. For example, Moody's has changed its sovereign bond methodology to capture the effects of physical climate change in a broad set of rating factors that influence a sovereign's ability and willingness to repay its debt (Moody's, 2016). Over recent years, rating agencies have reinforced their expertise in climate risk rating by acquiring agencies specialized in corporate environmental performance ratings.

We acknowledge that credit ratings are not perfectly correlated with publicly observable and quantifiable information about firms' characteristics and that they bring a holistic creditworthiness assessment beyond financial and accounting ratios. Nevertheless, variables such as interest coverage, profitability, size, and risk measures are well-known determinants of rating levels and their corresponding expected default losses (see, for example, Standard and Poor's corporate rating criteria, 2013). To check whether credit ratings reflect climate risk, we estimate the following equation in columns (1) and (2) of Table 7: 


$$
\text { CreditRating }_{i t}=\alpha+\beta_{1} \text { Climate risk }_{i}+\beta_{2} X_{i t}+\beta_{3} Z_{i t}+\varepsilon_{i t}
$$

CreditRating $_{i t}$ refers to our linearized credit rating variable or to alternative variables, such as NoCreditRating, Grade variation, Downgrade and Upgrade, Climate risk ${ }_{i}$ represents the overall risk exposure of a firm, $X_{i t}$ is a vector of controls that have been shown to affect the level of credit ratings, and $Z_{i t}$ is a vector of fixed effects. For regressions (2) and (4) of Table 7, Climate risk is interacted with Post2015, which is a dummy equal to one after 2015.

We first examine rated firms. In this subsample, we regress the credit rating variable on the following explanatory variables: profitability; interest coverage; size; age; Tobin's Q; working capital divided by total assets; operating expenses divided by total assets; R\&D expenses divided by total assets; and the fraction of tangible assets. We control for year fixed effects to consider not only that rating standards have tightened over time (see Jorion et al. (2009); Baghai et al. (2014)) but also country-industry fixed effects (as business risk varies across sectors and the sovereign rating represents in almost all cases a ceiling for the private sector). As the results in Table 7 indicate (columns 1 and 2), the coefficient of our climate risk variable is not significantly different from zero, either before or after 2015, which suggests that credit ratings do not reflect physical climate risk specific to the firm beyond the headquarter country climate risk that is captured by the country-industry dummies.

However, it may also be that a high level of climate risk may discourage rating agencies from rating these firms. Thus, only the companies with the lowest climate risk would be rated, which could explain the absence of any impact of climate risk on credit risk. We run a regression that explains the fact of not being rated (Table 7, columns 3 and 4). Again, the coefficient of our climate risk variable is not significantly different from zero either before or after 2015. A 
potential explanation might be that the level of credit ratings does not yet reflect physical climate risks but that these climate risks are triggering credit updates and conditional on having an update, are associated with lower new ratings. We test these intuitions in columns (5) to (7), and we do not find support for these hypotheses.

Accordingly, consistent with anecdotal evidence ${ }^{22}$, physical climate risk as measured by the CRIS ratings does not seem to be reflected in the credit ratings issued by the rating agencies, at least over the period that we examine.

\subsection{Robustness checks}

\subsubsection{Difference-in-differences around 2015}

Our analysis has thus far used the CRIS rating, a continuous variable, to explain firms' leverage. Our results identify a negative effect of physical climate risk on leverage concentrated in high climate risk firms and on the post-2015 period, i.e., after the Paris Agreement. A first question arises about the possibility of our climate risk measure being endogenous. Our climate risk measure is a forward-looking measure that reflects the probability of future climate events that are highly exogeneous. However, we acknowledge that this risk measure depends on the location of the firm's activities and the choice of business segments that are more or less vulnerable to climate risk, which are factors that may also impact the firm's leverage. To mitigate these potential endogeneity problems, we conduct additional tests in a difference-in-differences setting by using the 2015 Paris Agreement as a shock to banks and investors' awareness of physical climate risks. We first graphically check the parallel trend assumption and verify that it

\footnotetext{
${ }^{22}$ See the article released by Bloomberg here.
} 
is satisfied in the pre-treatment period, i.e., up to 2015. We then define 8 treatment variables based on the overall climate risk and on the 7 subrisk indicators. For each of the 8 risk indicators, a firm is considered to belong to the treated group if the risk indicator has a value above the $60^{\text {th }}$ percentile. Firms below the $40^{\text {th }}$ percentile fall into the control group. For a clearer distinction between the treatment and control groups, we exclude firms between the $40^{\text {th }}$ and $60^{\text {th }}$ percentiles. The results are reported in Table 8. Regression (1) reports a treatment effect of $-2.09 \%$ when defining the treatment with respect to the overall climate risk. This result is qualitatively similar to the result in Table 2, Panel A, column (6), which indicates a marginal effect of $-2.50 \%$ $\left(21 * 0,119 \%\right.$, the difference in the overall climate risk indicator between firms below the $40^{\text {th }}$

percentile and firms above the $60^{\text {th }}$ percentile being 21 points). Regressions (2) to (8) report the treatment effects when using the subrisk indicators to define the treated and control groups. Consistent with Table 4, we find significant treatment effects for droughts, heat waves, storms, heavy rainfall and sea level rise risks.

Overall, our results in a difference-in-differences setting are consistent with the findings highlighted in Tables 2 to 4 .

\subsubsection{CSR scores}

Because climate risk may also be part of a more general CSR assessment, our measure of climate risk could also be captured by CSR ratings. In Table 9, Panel A, we check whether our results remain unaffected after controlling for various CSR indicators. Regressions (1) and (2) use the general CSR score and the environmental pillar score given by the MSCI IVA ratings, respectively. Regressions (3) and (4) use two dummy variables based on CDP data (carbon disclosure): the first dummy variable equals 1 if the company has answered the CDP 
questionnaire, and the second dummy variable equals 1 if the company is rated A (best grade) by CDP. Whatever the measure for CSR performance, our results on the impact of climate risk on leverage are qualitatively unchanged, which suggests that our climate risk measure is not a mere proxy for CSR performance. Furthermore, the CSR variables in regressions (2) to (4) should be proxies for companies' awareness regarding climate change, and the CSR variable is predictive of behaviors that include insuring against weather events. To the best of our knowledge, no data source would allow us to capture weather insurance in an international setting, and this helps alleviate the concern that our results do not account for insurance mechanisms. In Table 9, Panel B, we construct subsamples based on the values of the CSR variables. Columns 1 and 2 report the regressions conducted on firms with an above-median overall CSR score and firms with below or equal to the median overall CSR score, respectively. Columns 3 and 4 report similar regressions on the subsamples based on the environmental scores. Our main results that firms' leverage decreases as their physical climate risk increases remain in the post-2015 period. In regressions (5) and (6), we analyze the firms that answered and did not answer the CDP, respectively. Firms that answered the CDP questionnaire tend to have experienced a weaker decrease of leverage with climate risk compared to firms that did not answer the questionnaire (the difference is significant at the $1 \%$ level). In regressions (7) and (8), we split our sample between firms included and firms not included on CDP's A list. Firms on the A list have had a smaller decrease in their leverage ratio post-2015 compared to firms not on the A list (the difference is significant at the 5\% level). Altogether, these results are consistent with the view that firms with better CSR scores are more likely to take proactive actions such as hedging their climate risk through insurance contracts, thereby reducing the need for a decrease in their debt ratio. The results are 
also consistent with Engle et al. (2019) who show that CSR acts as a hedge against physical and regulatory risks.

\subsubsection{Other robustness checks}

We conduct several other robustness checks. To consider the possibility of time effects that are specific to certain industries, we re-estimate our basic regressions (Table 2), including country and industry-year fixed effects, and the results remain unchanged. Similarly, the institutional characteristics of countries may evolve over time in different ways, but the patterns of the results are qualitatively similar when including country-year fixed effects. We also rerun our regressions, including several dummy variables for each level of credit rating rather than our linearized variable, and our results remain similar. Tables 3 and 4 report the results for only book leverage, but all of our results remain similar when we use market leverage as a dependent variable. Our results are also qualitatively unchanged when using country, industry and year fixed effects and clustering at the country-industry level, instead of using country-industry fixed effects and clustering at the firm level.

As an alternative to our 2050 horizon climate risk rating, we also use the 2100 horizon rating and low/high intensity risks, and the results are qualitatively unchanged, even if the coefficients of the variables change slightly depending on the chosen combination. We also verify that the results are robust to the exclusion of companies threatened by transition risks by running two additional regressions excluding the 5 and 10 largest carbon-emitting industries identified in Ilhan et al. (2019). We thus rule out the possibility that our findings account for transition risks rather than physical risks. Moreover, we also verify that these results are not driven by some particular industries, as they remain qualitatively unchanged after the exclusion 
of the 5 or 10 most represented in-sample industries or after elimination of the 5 most represented industries in each of the 2 risk-level groups.

\section{Conclusion}

In this paper, we analyze the impact of the climate risk rating on firms' leverage. We use a new forward-looking measure for physical climate risk at the firm level. Our work builds on the capital structure and climate risk literature. We find that firms exposed to a greater climate risk are less leveraged in the post-2015 period, i.e., after the Paris Agreement (COP21), and the Financial Stability Board call for standard measures and disclosures of climate risks. We also show that the reduction in debt related to climate risk is at least partly due to a supply effect. On the one hand, we find that in addition to firm characteristics known to determine leverage, including credit ratings and several fixed effects, an increased climate risk lowers the optimal leverage. On the other hand, we find that lenders charge higher interest rates to high climate risk companies. The effect is stronger for bank loans than for bond issues. This result is consistent with banks' local knowledge advantage documented in the literature and the recent concerns of central banks regarding climate risks. Furthermore, we find that the level of credit ratings, the probability of being rated and the probability of credit rating variations are independent of climate risks. We interpret these findings as an additional potential source of the differentiated impact between bank loans and bonds. Overall, our results suggest that over the recent period, climate risk has become an important factor in understanding the capital structure of firms. 


\section{References}

Addoum, J.M., Ng, D.T., Ortiz Bobea, A., 2019. Temperature shocks and earnings news. Unpublished working paper. Cornell University.

Agarwal, S., Hauswald, R., 2010. Distance and private information in lending. Review of Financial Studies 23, 2757-2788.

Amiraslani, H., Lins, K.V., Servaes, H., Tamayo, A., 2017. A matter of Trust? The bond market benefits of corporate social capital during the financial crisis. Unpublished working paper. London School of Economics, University of Utah, London Business School.

Andersson, M., Bolton, P., Samama, F., 2016a. Hedging climate risk. Financial Analysts Journal $72,13-32$.

Andersson, M., Bolton, P., Samama, F., 2016b. Governance and climate change: a success story in mobilizing investor support for corporate responses to climate change. Journal of Applied Corporate Finance 28, 29-33.

Baghai, R.P., Servaes, H., Tamayo, A., 2014. Have rating agencies become more conservative? Implications for capital structure and debt pricing. Journal of Finance 69, 1961-2005.

Baldauf, M., Garlappi, L., Yannelis, C., 2019. Does climate change affect real estate prices? Only if you believe in it. Review of Financial Studies, forthcoming.

Bansal, R., Kiku, D., Ochoa, M., 2016. Price of long-run temperature shifts in capital markets. Unpublished working paper. Duke University, NBER, University of Illinois at UrbanaChampaign, and Board of Governors of the Federal Reserve System.

Barrot, J.-N., Sauvagnat, J., 2016. Input specificity and the propagation of idiosyncratic shocks in production networks. The Quarterly Journal of Economics 131, 1543-1592.

Berg, T., Saunders, A., Steffen, S., 2016. The total cost of corporate borrowing in the loan market: don't ignore the fees. Journal of Finance 71, 1357-1392.

Berkman, H., Jona, J., Soderstrom, N., 2019. Firm-specific climate risk and market valuation. Unpublished working paper. University of Auckland, Tulane University, and University of Melbourne.

Bernstein, A., Gustafson, M., Lewis, R., 2019. Disaster on the horizon: the price effect of sea level rise. Journal of Financial Economics, forthcoming.

Bessembinder, H., Jacobsen, S., Maxwell, W., Venkataraman, K., 2018. Capital commitment and illiquidity in corporate bonds. Journal of Finance 73, 1615-1661.

Bolton, P., Kacperczyk, M.T., 2019. Do investors care about carbon risk? Unpublished working paper. Columbia Business School and Imperial College London.

Briere, M., Pouget, S., Ureche, L., 2019. Do universal owners vote to curb negative corporate externalities? An empirical analysis of shareholder meetings. Unpublished working paper. Amundi Asset Management, Toulouse School of Economics, and University of Picardy.

Campello, M., Giambona, E., 2013. Real assets and capital structure. Journal of Financial and Quantitative Analysis 48, 1333-1370.

Campiglio, E., Dafermos, Y., Monnin, P., Ryan-Collins, J., Schotten, G., Tanaka, M., 2018. Climate change challenges for central banks and financial regulators. Nature Climate Change 8, 462.

Carbon Tracker Initiative, 2013. Unburnable carbon 2013: wasted capital and stranded assets.

Carney, M., 2015. Breaking the tragedy of the horizon-climate change and financial stability. Speech given at Lloyd's of London, September 29.

Chang, X., Fu, K., Li, T., Tam, L., Wong, G., 2018. Corporate environmental liabilities and 
capital structure. Unpublished working paper. Nanyang Technological University, Hong Kong Baptist University, Central University of Finance and Economics, University of Macau, and The Hong Kong Polytechnic University.

Chava, S., 2014. Environmental externalities and cost of capital. Management Science 60, $2223-$ 2247.

Chava, S., Roberts, M.R., 2008. How does financing impact investment? The role of debt covenants. Journal of Finance 63, 2085-2121.

Daniel, K., Litterman, R., Wagner, G., 2016. Applying asset pricing theory to calibrate the price of climate risk. Unpublished working paper. Columbia University, Kepos Capital, and Harvard University.

Delis, M.D., de Greiff, K., Ongena, S., 2019. Being stranded with fossil fuel reserves? Climate policy risk and the pricing of bank loans. Unpublished working paper. Montpellier Business School, University of Zurich, Swiss Finance Institute.

Dell, M., Jones, B.F., Olken, B.A., 2014. What do we learn from the weather? The new climateeconomy literature. Journal of Economic Literature 52, 740-798.

El Ghoul, S., Guedhami, O., Kwok, C.C.Y., Mishra, D.R., 2011. Does corporate social responsibility affect the cost of capital? Journal of Banking \& Finance 35, 2388-2406.

Elnahas, A., Kim, D., Kim, I., 2018. Natural disaster risk and corporate leverage. Unpublished working paper. University of Texas Rio Grande Valley, and California State University San Marcos.

Engle, R.F., Giglio, S., Kelly, B.T., Lee, H., Stroebel, J., 2019. Hedging climate change news. Unpublished working paper. New York University, Yale University, and AQR Capital Management.

Faulkender, M., Petersen, M.A., 2005. Does the source of capital affect capital structure? Review of Financial Studies 19, 45-79.

Fischer, E.O., Heinkel, R., Zechner, J., 1989. Dynamic capital structure choice: theory and tests. Journal of Finance 44, 19-40.

Graham, J.R., 1996. Debt and the marginal tax rate. Journal of Financial Economics 41, 41-73.

Graham, J.R., Harvey, C.R., 2001. The theory and practice of corporate finance: evidence from the field. Journal of Financial Economics 60, 187-243.

Graham, J.R., Leary, M.T., 2011. A review of empirical capital structure research and directions for the future. Annual Review of Financial Economics 3, 309-345.

Graham, J.R., Lemmon, M.L., Schallheim, J.S., 1998. Debt, leases, taxes, and the endogeneity of corporate tax status. Journal of Finance 53, 131-162.

Hansen, L.P., Brock, W., Barnett, M., 2018. Pricing uncertainty induced by climate change. Unpublished working paper. University of Chicago, University of Wisconsin-Madison, and Arizona State University.

Helwege, J., Wang, L., 2017. Liquidity and price pressure in the corporate bond market: evidence from mega-bonds. Unpublished working paper. University of California, Riverside, and University of Nebraska-Lincoln.

Hertzel, M.G., Officer, M.S., 2012. Industry contagion in loan spreads. Journal of Financial Economics 103, 493-506.

Hong, H., Li, F.W., Xu, J., 2019. Climate risks and market efficiency. Journal of Econometrics 208, 265-281.

Hovakimian, A., Opler, T., Titman, S., 2001. The debt-equity choice. Journal of Financial and Quantitative Analysis 36, 1-24. 
Hugon, A., Law, K., 2019. Impact of climate change on firm earnings. Unpublished working paper. Arizona State University, and Nanyang Technological University.

Ilhan, E., Sautner, Z., Vilkov, G., 2019. Carbon tail risk. Unpublished working paper. Frankfurt School of Finance and Management, and ECGI.

Jones, B.F., Olken, B.A., 2010. Climate shocks and exports. American Economic Review 100, 454-459.

Jorion, P., Shi, C., Zhang, S., 2009. Tightening credit standards: the role of accounting quality. Review of Accounting Studies 14, 123-160.

Krueger, P., Sautner, Z., Starks, L.T., 2019. The importance of climate risks for institutional investors. Review of Financial Studies, forthcoming.

Kruttli, M., Roth Tran, B., Watugala, S.W., 2019. Pricing Poseidon: extreme weather uncertainty and firm return dynamics. Unpublished working paper. Board of Governors of the Federal Reserve System, University of Oxford, and Cornell University.

Leland, H.E., 1994. Corporate debt value, bond covenants, and optimal capital structure. Journal of Finance 49, 1213-1252.

McGlade, C., Ekins, P., 2015. The geographical distribution of fossil fuels unused when limiting global warming to $2{ }^{\circ} \mathrm{C}$. Nature 517,187 .

Monasterolo, I., De Angelis, L., 2018. Blind to carbon risk? An analysis of stock market's reaction to the Paris Agreement. Unpublished working paper. Vienna University of Economics and Business, and University of Bologna.

Moody's, 2016. How Moody's assesses the physical effects of climate change on sovereign issuers.

Painter, M., 2019. An inconvenient cost: the effects of climate change on municipal bonds. Journal of Financial Economics, forthcoming.

Petersen, M.A., 2009. Estimating standard errors in finance panel data sets: comparing approaches. Review of Financial Studies 22, 435-480.

Petersen, M.A., Rajan, R.G., 1994. The benefits of lending relationships: evidence from small business data. Journal of Finance 49, 3-37.

Rajan, R.G., 1992. Insiders and outsiders: the choice between informed and arm's-length debt. Journal of Finance 47, 1367-1400.

Rajan, R.G., Zingales, L., 1995. What do we know about capital structure? Some evidence from international data. Journal of Finance 50, 1421-1460.

Seltzer, L., Starks, L., Zhu, Q., 2019. Climate regulatory risks and corporate bonds. Unpublished working paper. University of Texas at Austin, and Nanyang Technological University.

Sharfman, M.P., Fernando, C.S., 2008. Environmental risk management and the cost of capital. Strategic Management Journal 29, 569-592.

Standard and Poors, 2013. Corporate ratings criteria.

Stern, N., 2008. The economics of climate change. American Economic Review 98, 1-37.

Strebulaev, I.A., Yang, B., 2013. The mystery of zero-leverage firms. Journal of Financial Economics 109, 1-23.

Titman, S., Wessels, R., 1988. The determinants of capital structure choice. Journal of Finance 43, 1-19.

Zerbib, O.D., 2019. The effect of pro-environmental preferences on bond prices: Evidence from green bonds. Journal of Banking \& Finance 98, 39-60. 


\section{Table 1}

Descriptive statistics.

This table reports summary statistics. Panel A presents the descriptive statistics for the CRIS climate variables. Each firm of the panel is covered by 8 CRIS climate grades (an overall rating and 7 subrisk ratings), computed on the basis of year 2016 figures. In Panel B, descriptive statistics of various firm-year characteristics are reported for the full sample. In Panel C, descriptive statistics of firm-year characteristics are disaggregated between low climate risk $\left(<40^{\text {th }}\right.$ percentile) and high climate risk $\left(>60^{\text {th }}\right.$ percentile) observations. In Panel $\mathrm{D}$, descriptive statistics of bank loan and borrower characteristics are reported for the full sample. In Panel E, descriptive statistics of bond and bond issuer characteristics are reported for the full sample. All Compustat, Thomson-Reuters, Dealscan and Bloomberg variables are winsorised at the 1st and 99th percentiles, except for CreditRating. The statistics for CreditRating are presented for the firms that are credit rated. See Appendix A for variable definitions and Appendix B for details regarding the variable CreditRating. The sample comprises all firms in the MSCI World index from 2010 to 2018, excluding financial firms (SIC 6000-6999).

Panel A. Climate risks

\begin{tabular}{|c|c|c|c|c|c|c|}
\hline & $\mathrm{N}$ & Mean & SD & Median & $\mathrm{P} 25$ & P75 \\
\hline Climate risk & 1,212 & 35.161 & 10.833 & 36.994 & 26.919 & 42.225 \\
\hline Heavy rainfall & 1,212 & 37.305 & 15.796 & 36.382 & 24.796 & 49.265 \\
\hline Heat waves & 1,212 & 31.828 & 10.562 & 30.511 & 24.858 & 38.969 \\
\hline Droughts & 1,212 & 29.795 & 10.338 & 31.130 & 21.354 & 37.947 \\
\hline Storms & 1,212 & 44.197 & 15.096 & 46.349 & 30.081 & 53.050 \\
\hline Sea level rise & 1,212 & 41.663 & 13.984 & 46.943 & 28.094 & 51.846 \\
\hline Temperature rise & 1,212 & 23.873 & 8.940 & 23.735 & 17.619 & 29.852 \\
\hline Rainfall patterns & 1,212 & 16.168 & 6.989 & 16.569 & 11.609 & 20.569 \\
\hline
\end{tabular}

Panel B. Firm-year characteristics

\begin{tabular}{|c|c|c|c|c|c|c|}
\hline & $\mathrm{N}$ & Mean & SD & Median & P25 & P75 \\
\hline BookLev & 10,240 & 0.215 & 0.158 & 0.198 & 0.099 & 0.308 \\
\hline MarketLev & 10,240 & 0.144 & 0.119 & 0.122 & 0.054 & 0.209 \\
\hline EBIT & 10,240 & 0.093 & 0.071 & 0.080 & 0.050 & 0.124 \\
\hline Log Age & 10,240 & 2.663 & 1.498 & 3.091 & 1.946 & 3.970 \\
\hline TobinQ & 10,240 & 1.970 & 1.392 & 1.515 & 1.157 & 2.197 \\
\hline OpEx & 10,240 & 0.700 & 0.535 & 0.569 & 0.336 & 0.891 \\
\hline R\&DExp & 10,240 & 0.020 & 0.036 & 0.001 & 0.000 & 0.025 \\
\hline PPE & 10,240 & 0.294 & 0.236 & 0.226 & 0.104 & 0.423 \\
\hline Log TotAssets & 10,240 & 9.348 & 1.221 & 9.272 & 8.530 & 10.187 \\
\hline CreditRating & 6,825 & 11.689 & 3.603 & 12.000 & 10.000 & 14.000 \\
\hline No CreditRating & 10,240 & 0.333 & 0.471 & 0.000 & 0.000 & 1.000 \\
\hline Log IntCoverage & 9,957 & 0.006 & 0.024 & 0.000 & 0.000 & 0.002 \\
\hline WorkCap & 10,240 & 0.134 & 0.173 & 0.100 & 0.006 & 0.227 \\
\hline CSR & 8,598 & 3.273 & 1.572 & 3.000 & 2.000 & 4.000 \\
\hline Environment score & 8,598 & 5.542 & 2.075 & 5.500 & 4.100 & 6.800 \\
\hline CDP answer & 5,790 & 0.772 & 0.420 & 1.000 & 1.000 & 1.000 \\
\hline A list & 5,790 & 0.154 & 0.361 & 0.000 & 0.000 & 0.000 \\
\hline
\end{tabular}


Panel C. High climate risk firms versus low climate risk firms

\begin{tabular}{|c|c|c|c|c|c|c|c|c|c|c|}
\hline & \multicolumn{5}{|c|}{ Low climate risk firms $\left(<40^{\text {th }}\right.$ percentile $)$} & \multicolumn{5}{|c|}{ High climate risk firms $\left(>60^{\text {th }}\right.$ percentile $)$} \\
\hline & Mean & SD & Median & $\mathrm{P} 25$ & P75 & Mean & SD & Median & $\mathrm{P} 25$ & P75 \\
\hline BookLev & 0.236 & 0.172 & 0.218 & 0.105 & 0.340 & 0.181 & 0.140 & 0.163 & 0.073 & 0.262 \\
\hline MarketLev & 0.151 & 0.126 & 0.129 & 0.053 & 0.220 & 0.133 & 0.116 & 0.108 & 0.042 & 0.197 \\
\hline EBIT & 0.102 & 0.075 & 0.087 & 0.054 & 0.135 & 0.084 & 0.067 & 0.072 & 0.046 & 0.109 \\
\hline Log Age & 2.385 & 1.473 & 2.833 & 1.099 & 3.497 & 2.952 & 1.487 & 3.526 & 2.565 & 4.127 \\
\hline TobinQ & 2.149 & 1.515 & 1.602 & 1.242 & 2.430 & 1.780 & 1.269 & 1.359 & 1.080 & 1.965 \\
\hline OpEx & 0.785 & 0.648 & 0.556 & 0.319 & 1.076 & 0.636 & 0.406 & 0.572 & 0.362 & 0.821 \\
\hline R\&DExp & 0.013 & 0.033 & 0.000 & 0.000 & 0.004 & 0.029 & 0.039 & 0.016 & 0.000 & 0.042 \\
\hline PPE & 0.251 & 0.225 & 0.182 & 0.062 & 0.386 & 0.320 & 0.227 & 0.254 & 0.146 & 0.423 \\
\hline Log TotAssets & 9.232 & 1.242 & 9.159 & 8.408 & 10.072 & 9.431 & 1.206 & 9.358 & 8.604 & 10.261 \\
\hline CreditRating & 11.259 & 3.443 & 12.000 & 10.000 & 13.000 & 12.158 & 3.865 & 13.000 & 11.000 & 15.000 \\
\hline No CreditRating & 0.347 & 0.476 & 0.000 & 0.000 & 1.000 & 0.381 & 0.486 & 0.000 & 0.000 & 1.000 \\
\hline Log IntCoverage & 0.008 & 0.028 & 0.000 & 0.000 & 0.002 & 0.005 & 0.022 & 0.000 & 0.000 & 0.001 \\
\hline WorkCap & 0.109 & 0.179 & 0.067 & -0.012 & 0.197 & 0.170 & 0.174 & 0.150 & 0.037 & 0.277 \\
\hline CSR & 3.218 & 1.586 & 3.000 & 2.000 & 4.000 & 3.363 & 1.530 & 3.000 & 2.000 & 5.000 \\
\hline Environment score & 5.877 & 2.216 & 5.700 & 4.280 & 7.400 & 5.454 & 1.875 & 5.500 & 4.280 & 6.700 \\
\hline CDP answer & 0.743 & 0.437 & 1.000 & 0.000 & 1.000 & 0.813 & 0.390 & 1.000 & 1.000 & 1.000 \\
\hline A list & 0.142 & 0.349 & 0.000 & 0.000 & 0.000 & 0.170 & 0.376 & 0.000 & 0.000 & 0.000 \\
\hline
\end{tabular}

Panel D. Bank loan and borrower characteristics

\begin{tabular}{lcccccc}
\hline & $\mathrm{N}$ & Mean & SD & Median & P25 & P75 \\
\hline Climate risk & 3,717 & 32.683 & 8.831 & 35.577 & 24.593 & 39.414 \\
Log Spread & 3,717 & 5.088 & 0.606 & 5.011 & 4.700 & 5.521 \\
Log Amount & 3,717 & 20.179 & 1.441 & 20.436 & 19.519 & 21.129 \\
Log Maturity & 3,717 & 4.116 & 0.189 & 4.094 & 4.094 & 4.094 \\
EBIT & 3,717 & 0.091 & 0.061 & 0.080 & 0.050 & 0.120 \\
Log Age & 3,717 & 2.935 & 1.289 & 3.219 & 2.639 & 3.970 \\
TobinQ & 3,717 & 1.820 & 0.983 & 1.502 & 1.211 & 2.076 \\
OpEx & 3,717 & 0.630 & 0.571 & 0.461 & 0.246 & 0.798 \\
R\&DExp & 3,717 & 0.013 & 0.026 & 0.000 & 0.000 & 0.014 \\
PPE & 3,717 & 0.268 & 0.261 & 0.167 & 0.056 & 0.442 \\
Log TotAssets & 3,717 & 9.657 & 1.149 & 9.631 & 8.824 & 10.447 \\
CreditRating & 3,208 & 10.796 & 3.337 & 11.000 & 9.000 & 13.000 \\
No Credit Rating & 3,717 & 0.137 & 0.344 & 0.000 & 0.000 & 0.000 \\
\hline
\end{tabular}

Panel E. Bond and bond issuer characteristics

\begin{tabular}{lcccccc}
\hline & $\mathrm{N}$ & Mean & SD & Median & P25 & P75 \\
\hline Climate risk & 4,435 & 34.131 & 10.841 & 36.343 & 25.093 & 41.119 \\
Log Spread & 4,435 & 4.795 & 0.873 & 4.877 & 4.443 & 5.298 \\
Log Amount & 4,435 & 20.213 & 0.691 & 20.212 & 19.807 & 20.723 \\
Log Maturity & 4,435 & 4.760 & 0.584 & 4.787 & 4.431 & 4.804 \\
EBIT & 4,435 & 0.092 & 0.064 & 0.081 & 0.050 & 0.123 \\
Log Age & 4,435 & 3.226 & 1.139 & 3.526 & 2.944 & 4.094 \\
TobinQ & 4,435 & 1.799 & 0.938 & 1.496 & 1.152 & 2.092 \\
OpEx & 4,435 & 0.630 & 0.607 & 0.422 & 0.263 & 0.754 \\
R\&DExp & 4,435 & 0.014 & 0.026 & 0.000 & 0.000 & 0.017 \\
PPE & 4,435 & 0.336 & 0.265 & 0.263 & 0.102 & 0.565 \\
Log TotAssets & 4,435 & 10.436 & 1.119 & 10.448 & 9.677 & 11.172 \\
CreditRating & 4,131 & 12.163 & 4.008 & 13.000 & 11.000 & 15.000 \\
No CreditRating & 4,435 & 0.069 & 0.253 & 0.000 & 0.000 & 0.000 \\
\hline
\end{tabular}




\section{Table 2}

Climate risk and long-term debt.

This table presents estimates of the effects of overall climate risk on the level of long-term debt. Panel A reports estimates using BookLev as dependent variable. Panel B reports estimates using MarketLev as dependent variable. Columns (1) to (6) report OLS estimates. Column (7) reports 2SLS estimates, where average value of CreditRating at country-industry-year level are instruments for CreditRating. Regressions (1), (2), (4) and (5) include industry and year fixed effects. Regressions (3), (6) and (7) include country-industry and year fixed effects. The sample comprises all firms in the MSCI World index from 2010 to 2018, excluding financial firms (SIC 6000-6999). Standard errors are clustered at the firm level. T-statistics are reported in parentheses. $* * * * *$, and $*$ indicate significance at the $1 \%, 5 \%$ and $10 \%$ levels, respectively.

Panel A. Book leverage

\begin{tabular}{|c|c|c|c|c|c|c|c|}
\hline VARIABLES & $\begin{array}{c}(1) \\
\text { BookLev }\end{array}$ & $\begin{array}{c}(2) \\
\text { BookLev } \\
\end{array}$ & $\begin{array}{c}(3) \\
\text { BookLev }\end{array}$ & $\begin{array}{c}(4) \\
\text { BookLev }\end{array}$ & $\begin{array}{c}(5) \\
\text { BookLev }\end{array}$ & $\begin{array}{c}(6) \\
\text { BookLev }\end{array}$ & $\begin{array}{c}(7) \\
\text { BookLev }\end{array}$ \\
\hline & \multicolumn{6}{|c|}{ OLS } & 2 SLS \\
\hline EBIT & $\begin{array}{l}-0.113^{*} \\
(-1.887)\end{array}$ & $\begin{array}{l}-0.111 * \\
(-1.848)\end{array}$ & $\begin{array}{c}-0.170 * * * \\
(-2.743)\end{array}$ & $\begin{array}{c}-0.152 * * * \\
(-2.646)\end{array}$ & $\begin{array}{c}-0.150 * * * \\
(-2.606)\end{array}$ & $\begin{array}{c}-0.184 * * * \\
(-3.028)\end{array}$ & $\begin{array}{c}-0.291 * * * \\
(-7.373)\end{array}$ \\
\hline Log Age & $\begin{array}{c}0.00435^{*} \\
(1.886)\end{array}$ & $\begin{array}{c}0.00433^{*} \\
(1.876)\end{array}$ & $\begin{array}{c}-1.15 \mathrm{e}-05 \\
(-0.00309)\end{array}$ & $\begin{array}{c}0.000995 \\
(0.435)\end{array}$ & $\begin{array}{c}0.000978 \\
(0.427)\end{array}$ & $\begin{array}{c}-0.00163 \\
(-0.447)\end{array}$ & $\begin{array}{c}0.00147 \\
(0.290)\end{array}$ \\
\hline TobinQ & $\begin{array}{c}0.00557 \\
(1.578)\end{array}$ & $\begin{array}{c}0.00554 \\
(1.571)\end{array}$ & $\begin{array}{c}-0.00313 \\
(-0.939)\end{array}$ & $\begin{array}{c}0.00620 * \\
(1.839)\end{array}$ & $\begin{array}{c}0.00617 * \\
(1.831)\end{array}$ & $\begin{array}{c}-0.00252 \\
(-0.765)\end{array}$ & $\begin{array}{c}0.00500^{*} \\
(1.914)\end{array}$ \\
\hline OpEx & $\begin{array}{c}-0.0486 * * * \\
(-4.831)\end{array}$ & $\begin{array}{c}-0.0488 * * * \\
(-4.847)\end{array}$ & $\begin{array}{c}-0.0421 * * * \\
(-3.672)\end{array}$ & $\begin{array}{c}-0.0512 * * * \\
(-5.192)\end{array}$ & $\begin{array}{c}-0.0514 * * * \\
(-5.208)\end{array}$ & $\begin{array}{c}-0.0434 * * * \\
(-3.816)\end{array}$ & $\begin{array}{c}-0.0330 * * * \\
(-3.454)\end{array}$ \\
\hline R\&DExp & $\begin{array}{c}-0.581 * * * \\
(-4.920)\end{array}$ & $\begin{array}{c}-0.584 * * * \\
(-4.951)\end{array}$ & $\begin{array}{c}-0.587 * * * \\
(-4.962)\end{array}$ & $\begin{array}{c}-0.565^{* * *} * \\
(-4.923)\end{array}$ & $\begin{array}{c}-0.568 * * * \\
(-4.955)\end{array}$ & $\begin{array}{c}-0.576 * * * \\
(-4.925)\end{array}$ & $\begin{array}{c}-0.293 * * * \\
(-3.141)\end{array}$ \\
\hline Log TotAssets & $\begin{array}{c}0.00994 * * * \\
(3.048)\end{array}$ & $\begin{array}{c}0.00974 * * * \\
(2.985)\end{array}$ & $\begin{array}{c}0.00389 \\
(1.012)\end{array}$ & $\begin{array}{c}0.000855 \\
(0.249)\end{array}$ & $\begin{array}{c}0.000661 \\
(0.193)\end{array}$ & $\begin{array}{c}0.000437 \\
(0.110)\end{array}$ & $\begin{array}{c}0.0166 * * * \\
(3.466)\end{array}$ \\
\hline PPE & $\begin{array}{c}0.0833 * * * \\
(2.914)\end{array}$ & $\begin{array}{c}0.0836 * * * \\
(2.923)\end{array}$ & $\begin{array}{c}0.102 * * * \\
(3.266)\end{array}$ & $\begin{array}{c}0.0802 * * * \\
(2.818)\end{array}$ & $\begin{array}{c}0.0804 * * * \\
(2.827)\end{array}$ & $\begin{array}{c}0.102 * * * \\
(3.239)\end{array}$ & $\begin{array}{c}0.119 * * * \\
(3.788)\end{array}$ \\
\hline CreditRating & & & & $\begin{array}{c}0.00425 * * * \\
(7.374)\end{array}$ & $\begin{array}{c}0.00425 * * * \\
(7.375)\end{array}$ & $\begin{array}{c}0.00184 * * * \\
(3.122)\end{array}$ & $\begin{array}{c}-0.000865 \\
(-1.168)\end{array}$ \\
\hline Climate risk & $\begin{array}{c}-0.00384 * * * \\
(-7.433)\end{array}$ & $\begin{array}{c}-0.00342 * * * \\
(-6.557)\end{array}$ & $\begin{array}{c}-0.00105 \\
(-1.558)\end{array}$ & $\begin{array}{c}-0.00348 * * * \\
(-6.849)\end{array}$ & $\begin{array}{c}-0.00307 * * * \\
(-5.960)\end{array}$ & $\begin{array}{c}-0.00105 \\
(-1.564)\end{array}$ & $\begin{array}{c}-0.000651 \\
(-0.984)\end{array}$ \\
\hline Climate risk*Post 2015 & & $\begin{array}{c}-0.00124 * * * \\
(-5.239)\end{array}$ & $\begin{array}{c}-0.00121 * * * \\
(-5.045)\end{array}$ & & $\begin{array}{c}-0.00123 * * * \\
(-5.078)\end{array}$ & $\begin{array}{c}-0.00119 * * * \\
(-4.972)\end{array}$ & $\begin{array}{c}-0.00119 * * * \\
(-5.231)\end{array}$ \\
\hline Constant & $\begin{array}{l}0.158 * * * \\
(3.183)\end{array}$ & $\begin{array}{c}0.145^{* * *} * \\
(2.919)\end{array}$ & $\begin{array}{c}0.189^{* * *} \\
(3.333)\end{array}$ & $\begin{array}{c}0.206 * * * \\
(4.279)\end{array}$ & $\begin{array}{c}0.193 * * * \\
(4.006)\end{array}$ & $\begin{array}{c}0.789 * * * \\
(11.79)\end{array}$ & $\begin{array}{l}0.0412 \\
(0.635)\end{array}$ \\
\hline Observations & 10,240 & 10,240 & 10,240 & 10,240 & 10,240 & 10,240 & 10,240 \\
\hline R-squared & 0.283 & 0.285 & 0.508 & 0.303 & 0.305 & 0.511 & \\
\hline Industry Fixed Effects & Yes & Yes & - & Yes & Yes & - & - \\
\hline $\begin{array}{l}\text { Country-Industry } \\
\text { Fixed Effects }\end{array}$ & No & No & Yes & No & No & Yes & Yes \\
\hline $\begin{array}{l}\text { Year Fixed Effects } \\
\text { Number of firms }\end{array}$ & Yes & Yes & Yes & Yes & Yes & Yes & $\begin{array}{c}\text { Yes } \\
1,212\end{array}$ \\
\hline
\end{tabular}


Panel B. Market leverage

\begin{tabular}{|c|c|c|c|c|c|c|c|}
\hline VARIABLES & $\begin{array}{c}\text { (1) } \\
\text { MarketLev }\end{array}$ & $\begin{array}{c}\text { (2) } \\
\text { MarketLev }\end{array}$ & $\begin{array}{c}\text { (3) } \\
\text { MarketLev }\end{array}$ & $\begin{array}{c}\text { (4) } \\
\text { MarketLev }\end{array}$ & $\begin{array}{c}(5) \\
\text { MarketLev }\end{array}$ & $\begin{array}{c}(6) \\
\text { MarketLev }\end{array}$ & $\begin{array}{c}(7) \\
\text { MarketLev }\end{array}$ \\
\hline & \multicolumn{6}{|c|}{ OLS } & 2 SLS \\
\hline EBIT & $\begin{array}{c}-0.281 * * * \\
(-9.725)\end{array}$ & $\begin{array}{c}-0.280 * * * \\
(-9.694)\end{array}$ & $\begin{array}{c}-0.303^{* * * *} \\
(-9.929)\end{array}$ & $\begin{array}{c}-0.294 * * * \\
(-10.34)\end{array}$ & $\begin{array}{c}-0.293 * * * \\
(-10.31)\end{array}$ & $\begin{array}{c}-0.302^{* * * *} \\
(-9.971)\end{array}$ & $\begin{array}{c}-0.329 * * * \\
(-11.58)\end{array}$ \\
\hline Log Age & $\begin{array}{c}0.000292 \\
(0.189)\end{array}$ & $\begin{array}{c}0.000284 \\
(0.184)\end{array}$ & $\begin{array}{c}-0.00359 \\
(-1.389)\end{array}$ & $\begin{array}{c}-0.000876 \\
(-0.560)\end{array}$ & $\begin{array}{c}-0.000883 \\
(-0.565)\end{array}$ & $\begin{array}{c}-0.00342 \\
(-1.337)\end{array}$ & $\begin{array}{c}-0.00809 * * \\
(-2.132)\end{array}$ \\
\hline TobinQ & $\begin{array}{c}-0.0126 * * * \\
(-7.354)\end{array}$ & $\begin{array}{c}-0.0126 * * * \\
(-7.372)\end{array}$ & $\begin{array}{c}-0.0167 * * * \\
(-8.574)\end{array}$ & $\begin{array}{c}-0.0124 * * * \\
(-7.309)\end{array}$ & $\begin{array}{c}-0.0124 * * * \\
(-7.327)\end{array}$ & $\begin{array}{c}-0.0167 * * * \\
(-8.510)\end{array}$ & $\begin{array}{c}-0.0135 * * * \\
(-7.872)\end{array}$ \\
\hline OpEx & $\begin{array}{c}-0.0325 * * * \\
(-4.952)\end{array}$ & $\begin{array}{c}-0.0326 * * * \\
(-4.962)\end{array}$ & $\begin{array}{c}-0.0280 * * * \\
(-3.640)\end{array}$ & $\begin{array}{c}-0.0334 * * * \\
(-5.143)\end{array}$ & $\begin{array}{c}-0.0335 * * * \\
(-5.153)\end{array}$ & $\begin{array}{c}-0.0278 * * * \\
(-3.629)\end{array}$ & $\begin{array}{c}-0.0248 * * * \\
(-3.458)\end{array}$ \\
\hline R\&DExp & $\begin{array}{c}-0.399 * * * \\
(-6.105)\end{array}$ & $\begin{array}{c}-0.401 * * * \\
(-6.135)\end{array}$ & $\begin{array}{c}-0.437 * * * \\
(-6.372)\end{array}$ & $\begin{array}{c}-0.394 * * * \\
(-6.070)\end{array}$ & $\begin{array}{c}-0.395 * * * \\
(-6.100)\end{array}$ & $\begin{array}{c}-0.438 * * * \\
(-6.365)\end{array}$ & $\begin{array}{c}-0.214 * * * \\
(-5.014)\end{array}$ \\
\hline Log TotAssets & $\begin{array}{c}0.0118 * * * \\
(5.479)\end{array}$ & $\begin{array}{c}0.0117 * * * \\
(5.437)\end{array}$ & $\begin{array}{c}0.00789 * * * \\
(3.044)\end{array}$ & $\begin{array}{c}0.00864 * * * \\
(3.787)\end{array}$ & $\begin{array}{c}0.00856 * * * \\
(3.754)\end{array}$ & $\begin{array}{c}0.00823 * * * \\
(3.060)\end{array}$ & $\begin{array}{c}0.0180 * * * \\
(5.277)\end{array}$ \\
\hline PPE & $\begin{array}{c}0.0669 * * * \\
(3.211)\end{array}$ & $\begin{array}{c}0.0670 * * * \\
(3.217)\end{array}$ & $\begin{array}{c}0.0830 * * * \\
(3.819)\end{array}$ & $\begin{array}{c}0.0658 * * * \\
(3.160)\end{array}$ & $\begin{array}{c}0.0659 * * * \\
(3.165)\end{array}$ & $\begin{array}{c}0.0831 * * * \\
(3.824)\end{array}$ & $\begin{array}{c}0.0796 * * * \\
(3.097)\end{array}$ \\
\hline CreditRating & & & & $\begin{array}{c}0.00148 * * * \\
(3.995)\end{array}$ & $\begin{array}{c}0.00148 * * * \\
(3.994)\end{array}$ & $\begin{array}{c}-0.000186 \\
(-0.489)\end{array}$ & $\begin{array}{c}-0.000773 \\
(-1.599)\end{array}$ \\
\hline Climate risk & $\begin{array}{c}-0.00157 * * * \\
(-4.216)\end{array}$ & $\begin{array}{c}-0.00140 * * * \\
(-3.686)\end{array}$ & $\begin{array}{c}-0.000866^{* *} \\
(-1.975)\end{array}$ & $\begin{array}{c}-0.00144 * * * \\
(-3.852)\end{array}$ & $\begin{array}{c}-0.00127 * * * \\
(-3.339)\end{array}$ & $\begin{array}{c}-0.000866^{* * *} \\
(-1.975)\end{array}$ & $\begin{array}{c}-0.000672 \\
(-1.550)\end{array}$ \\
\hline Climate risk*Post 2015 & & $\begin{array}{c}-0.000503 * * * \\
(-3.096)\end{array}$ & $\begin{array}{c}-0.000478 * * * \\
(-2.993)\end{array}$ & & $\begin{array}{c}-0.000498 * * * \\
(-3.020)\end{array}$ & $\begin{array}{c}-0.000479 * * * \\
(-3.002)\end{array}$ & $\begin{array}{c}-0.000436 * * * \\
(-2.852)\end{array}$ \\
\hline Constant & $\begin{array}{c}0.0942 * * * \\
(2.776)\end{array}$ & $\begin{array}{c}0.0889 * * * \\
(2.620)\end{array}$ & $\begin{array}{c}0.200 * * * \\
(5.238)\end{array}$ & $\begin{array}{c}0.111 * * * \\
(3.310)\end{array}$ & $\begin{array}{c}0.106^{* * * *} \\
(3.150)\end{array}$ & $\begin{array}{c}0.430 * * * \\
(9.739)\end{array}$ & $\begin{array}{c}0.115^{* * * *} \\
(2.701)\end{array}$ \\
\hline Observations & 10,240 & 10,240 & 10,240 & 10,240 & 10,240 & 10,240 & 10,240 \\
\hline R-squared & 0.435 & 0.436 & 0.600 & 0.440 & 0.440 & 0.600 & \\
\hline Industry Fixed Effects & Yes & Yes & - & Yes & Yes & - & - \\
\hline $\begin{array}{l}\text { Country-Industry } \\
\text { Fixed Effects }\end{array}$ & No & No & Yes & No & No & Yes & Yes \\
\hline $\begin{array}{l}\text { Year Fixed Effects } \\
\text { Number of firms }\end{array}$ & Yes & Yes & Yes & Yes & Yes & Yes & $\begin{array}{c}\text { Yes } \\
1,212 \\
\end{array}$ \\
\hline
\end{tabular}




\section{Table 3}

Climate risk and long-term debt: sample decomposition between high-risk group and low-risk group.

This table presents estimates of the effects of overall climate risk on the level of long-term debt, using BookLev as dependent variable. Columns (1) to (3) report OLS regressions conducted on the high-risk group (above the $60^{\text {th }}$ percentile). Columns (4) to (6) report OLS regressions conducted on the low-risk group (below the $40^{\text {th }}$ percentile). Regressions (1), (2), (4) and (5) include industry and year fixed effects. Regressions (3) and (6) include country-industry and year fixed effects. The sample comprises all firms in the MSCI World index from 2010 to 2018, excluding financial firms (SIC 6000-6999). Standard errors are clustered at the firm level. Tstatistics are reported in parentheses. $* * *, * *$, and $*$ indicate significance at the $1 \%, 5 \%$ and $10 \%$ levels, respectively.

\begin{tabular}{|c|c|c|c|c|c|c|}
\hline VARIABLES & $\begin{array}{c}(1) \\
\text { BookLev }\end{array}$ & $\begin{array}{c}(2) \\
\text { BookLev }\end{array}$ & $\begin{array}{c}(3) \\
\text { BookLev } \\
\end{array}$ & $\begin{array}{c}(4) \\
\text { BookLev }\end{array}$ & $\begin{array}{c}(5) \\
\text { BookLev } \\
\end{array}$ & $\begin{array}{c}(6) \\
\text { BookLev } \\
\end{array}$ \\
\hline & \multicolumn{3}{|c|}{ High climate risk subsample } & \multicolumn{3}{|c|}{ Low climate risk subsample } \\
\hline EBIT & $\begin{array}{c}-0.307 * * * \\
(-3.207)\end{array}$ & $\begin{array}{c}-0.298 * * * \\
(-3.124)\end{array}$ & $\begin{array}{c}-0.319 * * * \\
(-3.199)\end{array}$ & $\begin{array}{l}-0.0893 \\
(-0.973)\end{array}$ & $\begin{array}{l}-0.0869 \\
(-0.946)\end{array}$ & $\begin{array}{l}-0.0664 \\
(-0.709)\end{array}$ \\
\hline Log Age & $\begin{array}{c}-0.000494 \\
(-0.151)\end{array}$ & $\begin{array}{c}-0.000554 \\
(-0.169)\end{array}$ & $\begin{array}{c}0.00249 \\
(0.540)\end{array}$ & $\begin{array}{c}0.00422 \\
(0.889)\end{array}$ & $\begin{array}{c}0.00424 \\
(0.893)\end{array}$ & $\begin{array}{c}-0.00257 \\
(-0.305)\end{array}$ \\
\hline TobinQ & $\begin{array}{c}0.0106 * * \\
(2.004)\end{array}$ & $\begin{array}{c}0.0104 * * \\
(1.984)\end{array}$ & $\begin{array}{c}-0.00541 \\
(-1.078)\end{array}$ & $\begin{array}{c}0.00216 \\
(0.431)\end{array}$ & $\begin{array}{c}0.00199 \\
(0.398)\end{array}$ & $\begin{array}{c}-0.00464 \\
(-0.987)\end{array}$ \\
\hline OpEx & $\begin{array}{c}-0.0469 * * * \\
(-3.016)\end{array}$ & $\begin{array}{c}-0.0468 * * * \\
(-3.007)\end{array}$ & $\begin{array}{l}-0.0157 \\
(-0.970)\end{array}$ & $\begin{array}{c}-0.0496 * * * \\
(-3.012)\end{array}$ & $\begin{array}{c}-0.0498 * * * \\
(-3.022)\end{array}$ & $\begin{array}{c}-0.0486^{* * *} \\
(-2.581)\end{array}$ \\
\hline R\&DExp & $\begin{array}{l}-0.319 * \\
(-1.916)\end{array}$ & $\begin{array}{l}-0.317 * \\
(-1.908)\end{array}$ & $\begin{array}{c}-0.304 * * \\
(-2.087)\end{array}$ & $\begin{array}{c}-0.864 * * * \\
(-4.979)\end{array}$ & $\begin{array}{c}-0.857 * * * \\
(-4.921)\end{array}$ & $\begin{array}{c}-1.144 * * * \\
(-5.534)\end{array}$ \\
\hline Log TotAssets & $\begin{array}{c}0.00964 * * \\
(2.055)\end{array}$ & $\begin{array}{c}0.00945 * * \\
(2.017)\end{array}$ & $\begin{array}{c}0.0157 * * * \\
(3.280)\end{array}$ & $\begin{array}{c}-0.00190 \\
(-0.304)\end{array}$ & $\begin{array}{c}-0.00204 \\
(-0.328)\end{array}$ & $\begin{array}{c}-0.00946 \\
(-1.165)\end{array}$ \\
\hline PPE & $\begin{array}{c}0.0799 * * \\
(2.007)\end{array}$ & $\begin{array}{c}0.0799 * * \\
(2.010)\end{array}$ & $\begin{array}{c}0.120 * * * \\
(2.819)\end{array}$ & $\begin{array}{c}0.102 * * \\
(2.102)\end{array}$ & $\begin{array}{c}0.102 * * \\
(2.112)\end{array}$ & $\begin{array}{c}0.143 * * \\
(2.458)\end{array}$ \\
\hline CreditRating & $\begin{array}{c}0.00368 * * * \\
(5.078)\end{array}$ & $\begin{array}{c}0.00369 * * * \\
(5.088)\end{array}$ & $\begin{array}{c}0.00158 * * \\
(2.412)\end{array}$ & $\begin{array}{c}0.00403 * * * \\
(3.569)\end{array}$ & $\begin{array}{c}0.00404 * * * \\
(3.578)\end{array}$ & $\begin{array}{c}0.00196 \\
(1.504)\end{array}$ \\
\hline Climate risk & $\begin{array}{c}-0.00423 * * * \\
(-3.548)\end{array}$ & $\begin{array}{c}-0.00324 * * * \\
(-2.734)\end{array}$ & $\begin{array}{c}-0.000344 \\
(-0.238)\end{array}$ & $\begin{array}{c}-0.00464 * * * \\
(-3.238)\end{array}$ & $\begin{array}{c}-0.00424 * * * \\
(-2.964)\end{array}$ & $\begin{array}{c}-0.00278 \\
(-1.521)\end{array}$ \\
\hline Climate risk*Post2015 & & $\begin{array}{c}-0.00290 * * * \\
(-4.658)\end{array}$ & $\begin{array}{c}-0.00275^{* * * *} \\
(-4.287)\end{array}$ & & $\begin{array}{c}-0.00118 \\
(-1.619)\end{array}$ & $\begin{array}{c}-0.00106 \\
(-1.501)\end{array}$ \\
\hline Constant & $\begin{array}{c}0.178 * * \\
(2.069)\end{array}$ & $\begin{array}{c}0.135 \\
(1.581)\end{array}$ & $\begin{array}{l}-0.0365 \\
(-0.336)\end{array}$ & $\begin{array}{c}0.175 * * \\
(2.303)\end{array}$ & $\begin{array}{l}0.167 * * \\
(2.204)\end{array}$ & $\begin{array}{c}0.537 * * \\
(2.274)\end{array}$ \\
\hline Observations & 4,091 & 4,091 & 4,091 & 4,092 & 4,092 & 4,092 \\
\hline R-squared & 0.350 & 0.353 & 0.604 & 0.317 & 0.317 & 0.526 \\
\hline Industry Fixed Effects & Yes & Yes & - & Yes & Yes & - \\
\hline Country-Industry Fixed Effects & No & No & Yes & No & No & Yes \\
\hline Year Fixed Effects & Yes & Yes & Yes & Yes & Yes & Yes \\
\hline
\end{tabular}




\section{Table 4}

Climate subrisks and long-term debt.

This table presents estimates of the effects of climate subrisks on the level of long-term debt. Panel A reports OLS estimates using acute climate risks as independent variables. Panel B reports OLS estimates using chronic climate risks as independent variables. All regressions use BookLev as dependent variable. Regressions (1), (3), (5) and (7) include industry and year fixed effects. Regressions (2), (4), (6) and (8) include country-industry and year fixed effects. The sample comprises all firms in the MSCI World index from 2010 to 2018, excluding financial firms (SIC 6000-6999). Standard errors are clustered at the firm level. T-statistics are reported in parentheses. $* * * * *$, and $*$ indicate significance at the $1 \%, 5 \%$ and $10 \%$ levels, respectively.

Panel A. Acute physical climate risks

\begin{tabular}{|c|c|c|c|c|c|c|c|c|}
\hline VARIABLES & $\begin{array}{c}(1) \\
\text { BookLev }\end{array}$ & $\begin{array}{c}(2) \\
\text { BookLev } \\
\end{array}$ & $\begin{array}{c}(3) \\
\text { BookLev }\end{array}$ & $\begin{array}{c}(4) \\
\text { BookLev }\end{array}$ & $\begin{array}{c}5) \\
\text { BookLev }\end{array}$ & $\begin{array}{c}(6) \\
\text { BookLev }\end{array}$ & $\begin{array}{c}(7) \\
\text { BookLev } \\
\end{array}$ & $\begin{array}{c}(8) \\
\text { BookLev }\end{array}$ \\
\hline EBIT & $\begin{array}{c}-0.135 * * \\
(-2.348)\end{array}$ & $\begin{array}{c}-0.184 * * * \\
(-3.038)\end{array}$ & $\begin{array}{c}-0.145^{* *} * \\
(-2.525)\end{array}$ & $\begin{array}{c}-0.186^{* * * *} \\
(-3.073)\end{array}$ & $\begin{array}{c}-0.162 * * * \\
(-2.821)\end{array}$ & $\begin{array}{c}-0.185^{* * * *} \\
(-3.064)\end{array}$ & $\begin{array}{c}-0.141 * * \\
(-2.440)\end{array}$ & $\begin{array}{c}-0.174 * * * \\
(-2.857)\end{array}$ \\
\hline Log Age & $\begin{array}{r}-0.00167 \\
(-0.742)\end{array}$ & $\begin{array}{c}-0.00153 \\
(-0.420)\end{array}$ & $\begin{array}{l}-7.97 e-06 \\
(-0.00352)\end{array}$ & $\begin{array}{c}-0.00185 \\
(-0.508)\end{array}$ & $\begin{array}{c}0.00305 \\
(1.240)\end{array}$ & $\begin{array}{c}-0.00196 \\
(-0.537)\end{array}$ & $\begin{array}{c}-0.000730 \\
(-0.329)\end{array}$ & $\begin{array}{c}-0.00178 \\
(-0.486)\end{array}$ \\
\hline TobinQ & $\begin{array}{c}0.00685^{* * *} \\
(2.036)\end{array}$ & $\begin{array}{c}-0.00238 \\
(-0.725)\end{array}$ & $\begin{array}{c}0.00800^{* *} \\
(2.347)\end{array}$ & $\begin{array}{c}-0.00225 \\
(-0.682)\end{array}$ & $\begin{array}{c}0.00705^{* *} \\
(2.083)\end{array}$ & $\begin{array}{c}-0.00245 \\
(-0.744)\end{array}$ & $\begin{array}{c}0.00380 \\
(1.131)\end{array}$ & $\begin{array}{c}-0.00304 \\
(-0.925)\end{array}$ \\
\hline OpEx & $\begin{array}{c}-0.0516^{* * * *} \\
(-5.229)\end{array}$ & $\begin{array}{c}-0.0437 * * * \\
(-3.844)\end{array}$ & $\begin{array}{c}-0.0475 * * * \\
(-4.802)\end{array}$ & $\begin{array}{c}-0.0422 * * * * \\
(-3.702)\end{array}$ & $\begin{array}{c}-0.0514 * * * \\
(-5.200)\end{array}$ & $\begin{array}{c}-0.0438 * * * \\
(-3.848)\end{array}$ & $\begin{array}{c}-0.0527 * * * \\
(-5.519)\end{array}$ & $\begin{array}{c}-0.0435 * * * \\
(-3.838)\end{array}$ \\
\hline R\&DExp & $\begin{array}{c}-0.572 * * * \\
(-4.944)\end{array}$ & $\begin{array}{c}-0.587 \text { **** } \\
(-5.003)\end{array}$ & $\begin{array}{c}-0.528 * * * \\
(-4.522)\end{array}$ & $\begin{array}{c}-0.565^{* * * *} \\
(-4.788)\end{array}$ & $\begin{array}{c}-0.582 * * * \\
(-5.059)\end{array}$ & $\begin{array}{c}-0.585^{* * *} \\
(-5.004)\end{array}$ & $\begin{array}{c}-0.559 * * * \\
(-4.919)\end{array}$ & $\begin{array}{c}-0.573 * * * \\
(-4.891)\end{array}$ \\
\hline Log TotAssets & $\begin{array}{l}0.00238 \\
(0.689)\end{array}$ & $\begin{array}{c}0.000409 \\
(0.103)\end{array}$ & $\begin{array}{c}0.00291 \\
(0.838)\end{array}$ & $\begin{array}{c}0.00111 \\
(0.277)\end{array}$ & $\begin{array}{l}-0.000269 \\
(-0.0776)\end{array}$ & $\begin{array}{c}0.000269 \\
(0.0673)\end{array}$ & $\begin{array}{c}0.000357 \\
(0.105)\end{array}$ & $\begin{array}{c}0.000476 \\
(0.120)\end{array}$ \\
\hline PPE & $\begin{array}{c}0.0698 * * \\
(2.438)\end{array}$ & $\begin{array}{c}0.100 * * * \\
(3.193)\end{array}$ & $\begin{array}{c}0.0690 * * \\
(2.445)\end{array}$ & $\begin{array}{c}0.0972 * * * \\
(3.091)\end{array}$ & $\begin{array}{c}0.0725^{* *} \\
(2.530)\end{array}$ & $\begin{array}{c}0.0980 * * * \\
(3.117)\end{array}$ & $\begin{array}{c}0.0889 * * * \\
(3.186)\end{array}$ & $\begin{array}{c}0.104 * * * \\
(3.321)\end{array}$ \\
\hline CreditRating & $\begin{array}{c}0.00450 * * * \\
(7.793)\end{array}$ & $\begin{array}{c}0.00190 * * * \\
(3.205)\end{array}$ & $\begin{array}{c}0.00438 * * * \\
(7.570)\end{array}$ & $\begin{array}{c}0.00183 * * * \\
(3.070)\end{array}$ & $\begin{array}{c}0.00435 * * * \\
(7.489)\end{array}$ & $\begin{array}{c}0.00182 * * * \\
(3.047)\end{array}$ & $\begin{array}{c}0.00400^{* * * *} \\
(6.949)\end{array}$ & $\begin{array}{c}0.00186 * * * \\
(3.134)\end{array}$ \\
\hline Droughts & $\begin{array}{c}-0.00291 * * * \\
(-5.438)\end{array}$ & $\begin{array}{r}-0.00104 \\
(-1.488)\end{array}$ & & & & & & \\
\hline Droughts*Post 2015 & & $\begin{array}{c}-0.00118 * * * \\
(-4.572)\end{array}$ & & & & & & \\
\hline Heat waves & & & $\begin{array}{c}-0.00287 \text { *** } \\
(-6.072)\end{array}$ & $\begin{array}{c}-0.000422 \\
(-0.759)\end{array}$ & & & & \\
\hline Heat waves*Post 2015 & & & & $\begin{array}{c}-0.000915^{* * * *} \\
(-3.635)\end{array}$ & & & & \\
\hline Storms & & & & & $\begin{array}{c}-0.00198 * * * \\
(-6.016)\end{array}$ & $\begin{array}{c}-0.000448 \\
(-0.885)\end{array}$ & & \\
\hline Storms $*$ Post 2015 & & & & & & $\begin{array}{c}-0.000833 * * * \\
(-4.995)\end{array}$ & & \\
\hline Heavy rainfall & & & & & & & $\begin{array}{c}-0.00259 * * * \\
(-8.440)\end{array}$ & $\begin{array}{c}-0.000847^{*} \\
(-1.718)\end{array}$ \\
\hline Heavy rainfall*Post 2015 & & & & & & & & $\begin{array}{c}-0.000889 * * * \\
(-5.473)\end{array}$ \\
\hline Constant & $\begin{array}{l}0.165^{* * *} \\
(3.536)\end{array}$ & 0.126 & $\begin{array}{c}0.130 * * * \\
(2.901)\end{array}$ & $\begin{array}{l}0.166 * * * \\
(3.301)\end{array}$ & $\begin{array}{l}0.172 * * * \\
(3.625)\end{array}$ & $\begin{array}{c}0.196 * * * \\
(3.404)\end{array}$ & $\begin{array}{c}0.199 * * * \\
(4.259)\end{array}$ & $\begin{array}{c}0.221 * * * \\
(4.010)\end{array}$ \\
\hline Observations & 10,240 & 10,240 & 10,240 & 10,240 & 10,240 & 10,240 & 10,240 & 10,240 \\
\hline R-squared & 0.295 & 0.511 & 0.295 & 0.509 & 0.295 & 0.510 & 0.316 & 0.511 \\
\hline Industry Fixed Effects & Yes & - & Yes & - & Yes & - & Yes & - \\
\hline $\begin{array}{l}\text { Country-Industry Fixed } \\
\text { Effects }\end{array}$ & No & Yes & No & Yes & No & Yes & No & Yes \\
\hline Year Fixed Effects & Yes & Yes & Yes & Yes & Yes & Yes & Yes & Yes \\
\hline
\end{tabular}


Panel B. Chronic physical climate risks

\begin{tabular}{|c|c|c|c|c|c|c|}
\hline VARIABLES & $\begin{array}{c}(1) \\
\text { BookLev } \\
\end{array}$ & $\begin{array}{c}(2) \\
\text { BookLev } \\
\end{array}$ & $\begin{array}{c}(3) \\
\text { BookLev } \\
\end{array}$ & $\begin{array}{c}(4) \\
\text { BookLev } \\
\end{array}$ & $\begin{array}{c}(5) \\
\text { BookLev } \\
\end{array}$ & $\begin{array}{c}(6) \\
\text { BookLev } \\
\end{array}$ \\
\hline EBIT & $\begin{array}{c}-0.130 * * \\
(-2.261)\end{array}$ & $\begin{array}{c}-0.190 * * * \\
(-3.139)\end{array}$ & $\begin{array}{c}-0.118 * * \\
(-2.035)\end{array}$ & $\begin{array}{c}-0.187 * * * \\
(-3.072)\end{array}$ & $\begin{array}{c}-0.136 * * \\
(-2.373)\end{array}$ & $\begin{array}{c}-0.186 * * * \\
(-3.078)\end{array}$ \\
\hline Log Age & $\begin{array}{c}-0.00338 \\
(-1.489)\end{array}$ & $\begin{array}{c}-0.00170 \\
(-0.471)\end{array}$ & $\begin{array}{c}-0.00318 \\
(-1.402)\end{array}$ & $\begin{array}{c}-0.00138 \\
(-0.380)\end{array}$ & $\begin{array}{c}-0.00193 \\
(-0.840)\end{array}$ & $\begin{array}{c}-0.00196 \\
(-0.536)\end{array}$ \\
\hline TobinQ & $\begin{array}{c}0.00796^{* *} \\
(2.336)\end{array}$ & $\begin{array}{c}-0.00229 \\
(-0.694)\end{array}$ & $\begin{array}{c}0.00886^{* *} \\
(2.579)\end{array}$ & $\begin{array}{c}-0.00241 \\
(-0.732)\end{array}$ & $\begin{array}{c}0.00802 * * \\
(2.355)\end{array}$ & $\begin{array}{c}-0.00242 \\
(-0.735)\end{array}$ \\
\hline OpEx & $\begin{array}{c}-0.0525 * * * \\
(-5.305)\end{array}$ & $\begin{array}{c}-0.0423^{* * *} \\
(-3.719)\end{array}$ & $\begin{array}{c}-0.0511 * * * \\
(-5.123)\end{array}$ & $\begin{array}{c}-0.0416 * * * \\
(-3.652)\end{array}$ & $\begin{array}{c}-0.0534 * * * \\
(-5.320)\end{array}$ & $\begin{array}{c}-0.0440 * * * \\
(-3.879)\end{array}$ \\
\hline R\&DExp & $\begin{array}{c}-0.581 * * * \\
(-4.904)\end{array}$ & $\begin{array}{c}-0.574 * * * \\
(-4.883)\end{array}$ & $\begin{array}{c}-0.572 * * * \\
(-4.804)\end{array}$ & $\begin{array}{c}-0.577 * * * \\
(-4.908)\end{array}$ & $\begin{array}{c}-0.579 * * * \\
(-4.946)\end{array}$ & $\begin{array}{c}-0.583 * * * \\
(-4.982)\end{array}$ \\
\hline Log TotAssets & $\begin{array}{c}0.000880 \\
(0.252)\end{array}$ & $\begin{array}{c}0.00113 \\
(0.283)\end{array}$ & $\begin{array}{c}0.00298 \\
(0.841)\end{array}$ & $\begin{array}{c}0.00141 \\
(0.353)\end{array}$ & $\begin{array}{c}0.00103 \\
(0.295)\end{array}$ & $\begin{array}{c}0.000355 \\
(0.0891)\end{array}$ \\
\hline PPE & $\begin{array}{c}0.0557 * * \\
(1.962)\end{array}$ & $\begin{array}{c}0.0981 * * * \\
(3.112)\end{array}$ & $\begin{array}{c}0.0624 * * \\
(2.189)\end{array}$ & $\begin{array}{c}0.103 * * * \\
(3.298)\end{array}$ & $\begin{array}{c}0.0644 * * \\
(2.233)\end{array}$ & $\begin{array}{c}0.100 * * * \\
(3.178)\end{array}$ \\
\hline CreditRating & $\begin{array}{c}0.00473 * * * \\
(8.044)\end{array}$ & $\begin{array}{c}0.00183 * * * \\
(3.094)\end{array}$ & $\begin{array}{c}0.00483 * * * \\
(8.285)\end{array}$ & $\begin{array}{c}0.00191 * * * \\
(3.214)\end{array}$ & $\begin{array}{c}0.00469 * * * \\
(8.045)\end{array}$ & $\begin{array}{c}0.00187 * * * \\
(3.170)\end{array}$ \\
\hline Temperature rise & $\begin{array}{c}0.00119 * \\
(1.905)\end{array}$ & $\begin{array}{c}-0.000688 \\
(-0.972)\end{array}$ & & & & \\
\hline Temperature rise*Post 2015 & & $\begin{array}{l}-2.60 \mathrm{e}-05 \\
(-0.0842)\end{array}$ & & & & \\
\hline Rainfall patterns & & & $\begin{array}{c}-0.00174 * * \\
(-2.561)\end{array}$ & $\begin{array}{c}-0.00183 * * \\
(-2.080)\end{array}$ & & \\
\hline Rainfall patterns*Post 2015 & & & & $\begin{array}{c}-0.000533 \\
(-1.392)\end{array}$ & & \\
\hline Sea level rise & & & & & $\begin{array}{c}-0.00137 * * * \\
(-3.249)\end{array}$ & $\begin{array}{c}-0.000427 \\
(-0.850)\end{array}$ \\
\hline Sea level rise*Post 2015 & & & & & & $\begin{array}{c}-0.000668 * * * \\
(-3.361)\end{array}$ \\
\hline Constant & $\begin{array}{l}0.0540 \\
(1.197)\end{array}$ & $\begin{array}{c}0.173 * * * \\
(3.410)\end{array}$ & $\begin{array}{c}0.0959 * * \\
(2.142)\end{array}$ & $\begin{array}{c}0.192 * * * \\
(3.724)\end{array}$ & $\begin{array}{c}0.145 * * * \\
(2.992)\end{array}$ & $\begin{array}{c}0.194 * * * \\
(3.425)\end{array}$ \\
\hline Observations & 10,240 & 10,240 & 10,240 & 10,240 & 10,240 & 10,240 \\
\hline R-squared & 0.280 & 0.508 & 0.281 & 0.509 & 0.284 & 0.509 \\
\hline Industry Fixed Effects & Yes & - & Yes & - & Yes & - \\
\hline Country-Industry Fixed Effects & No & Yes & No & Yes & No & Yes \\
\hline Year Fixed Effects & Yes & Yes & Yes & Yes & Yes & Yes \\
\hline
\end{tabular}




\section{Table 5}

Climate risk and cost of bond loans.

This table presents estimates of the effects of overall climate risk on the cost of bond loans, using Log Spread as dependent variable. Columns (1) to (3) report OLS estimates on bonds having a maturity of more than 3 years. Column (4) to (6) report OLS estimates on loans having a maturity of at least 5 years. Regressions (1) and (4) are conducted on the total sample. Regressions (2) and (5) cover the high-risk companies over the $60^{\text {th }}$ percentile, regressions (3) and (6) cover the low-risk companies under the $40^{\text {th }}$ percentile. All regressions include country, industry, loan characteristics (number of loans to the company on the same date, loan purpose and secured/unsecured) and year fixed effects. The total sample comprises all firms in the MSCI World index from 2010 to 2018, excluding financial firms (SIC 6000-6999). Standard errors are double-clustered at the country-industry level. T-statistics are reported in parentheses. $* * *, * *$, and $*$ indicate significance at the $1 \%, 5 \%$ and $10 \%$ levels, respectively.

\begin{tabular}{|c|c|c|c|c|c|c|}
\hline VARIABLES & $\begin{array}{c}(1) \\
\text { Log Spread } \\
\end{array}$ & $\begin{array}{c}(2) \\
\text { Log Spread } \\
\end{array}$ & $\begin{array}{c}(3) \\
\text { Log Spread } \\
\end{array}$ & $\begin{array}{c}(4) \\
\text { Log Spread } \\
\end{array}$ & $\begin{array}{c}(5) \\
\text { Log Spread } \\
\end{array}$ & $\begin{array}{c}\text { (6) } \\
\text { Log Spread }\end{array}$ \\
\hline & \multicolumn{3}{|c|}{ Maturity $>3$ years } & \multicolumn{3}{|c|}{ Maturity $>5$ years } \\
\hline & Total sample & High risk & Low risk & Total sample & High risk & Low risk \\
\hline Log Amount & $\begin{array}{c}0.188^{* * * *} \\
(7.093)\end{array}$ & $\begin{array}{c}0.180 * * * \\
(4.222)\end{array}$ & $\begin{array}{c}0.149 * * * \\
(3.690)\end{array}$ & $\begin{array}{c}0.193^{* * * *} \\
(7.562)\end{array}$ & $\begin{array}{c}0.182 * * * \\
(4.183)\end{array}$ & $\begin{array}{c}0.150 * * * \\
(3.767)\end{array}$ \\
\hline Log Maturity & $\begin{array}{c}0.831 * * * \\
(7.254)\end{array}$ & $\begin{array}{c}0.875^{* * * *} \\
(4.190)\end{array}$ & $\begin{array}{c}0.908 * * * \\
(7.129)\end{array}$ & $\begin{array}{c}0.813 * * * \\
(7.091)\end{array}$ & $\begin{array}{c}0.835 * * * \\
(3.678)\end{array}$ & $\begin{array}{c}0.919 * * * \\
(7.509)\end{array}$ \\
\hline EBIT & $\begin{array}{c}-2.339 * * * \\
(-6.167)\end{array}$ & $\begin{array}{c}-2.179 * * * \\
(-3.299)\end{array}$ & $\begin{array}{c}-3.118 * * * \\
(-6.171)\end{array}$ & $\begin{array}{c}-2.281 * * * \\
(-6.293)\end{array}$ & $\begin{array}{c}-2.002 * * * \\
(-3.284)\end{array}$ & $\begin{array}{c}-3.070 * * * \\
(-6.197)\end{array}$ \\
\hline Log Age & $\begin{array}{l}-0.0327 \\
(-1.430)\end{array}$ & $\begin{array}{c}-0.0743^{*} \\
(-1.905)\end{array}$ & $\begin{array}{c}-0.00618 \\
(-0.161)\end{array}$ & $\begin{array}{l}-0.0309 \\
(-1.389)\end{array}$ & $\begin{array}{l}-0.0718^{*} \\
(-1.838)\end{array}$ & $\begin{array}{c}-0.00864 \\
(-0.232)\end{array}$ \\
\hline Tobin Q & $\begin{array}{c}-0.121 * * * \\
(-4.239)\end{array}$ & $\begin{array}{l}-0.151 * * \\
(-2.330)\end{array}$ & $\begin{array}{l}-0.0604 \\
(-1.395)\end{array}$ & $\begin{array}{c}-0.125 * * * \\
(-4.625)\end{array}$ & $\begin{array}{c}-0.158 * * \\
(-2.492)\end{array}$ & $\begin{array}{l}-0.0625 \\
(-1.497)\end{array}$ \\
\hline OpEx & $\begin{array}{l}-0.0339 \\
(-0.635)\end{array}$ & $\begin{array}{l}-0.0241 \\
(-0.180)\end{array}$ & $\begin{array}{l}-0.0461 \\
(-0.541)\end{array}$ & $\begin{array}{l}-0.0359 \\
(-0.672)\end{array}$ & $\begin{array}{l}-0.0450 \\
(-0.332)\end{array}$ & $\begin{array}{l}-0.0542 \\
(-0.638)\end{array}$ \\
\hline R\&DExp & $\begin{array}{l}-1.429 \\
(-1.199)\end{array}$ & $\begin{array}{c}0.675 \\
(0.703)\end{array}$ & $\begin{array}{l}-3.607 * \\
(-1.915)\end{array}$ & $\begin{array}{c}-1.319 \\
(-1.096)\end{array}$ & $\begin{array}{c}0.876 \\
(1.051)\end{array}$ & $\begin{array}{l}-3.579 * \\
(-1.886)\end{array}$ \\
\hline Log TotAssets & $\begin{array}{c}-0.239 * * * \\
(-9.747)\end{array}$ & $\begin{array}{c}-0.253 * * * \\
(-6.153)\end{array}$ & $\begin{array}{c}-0.243 * * * \\
(-7.348)\end{array}$ & $\begin{array}{c}-0.243 * * * \\
(-10.37)\end{array}$ & $\begin{array}{c}-0.257 * * * \\
(-6.439)\end{array}$ & $\begin{array}{c}-0.245 * * * \\
(-7.712)\end{array}$ \\
\hline PPE & $\begin{array}{c}-0.272 \\
(-1.451)\end{array}$ & $\begin{array}{c}-0.608 \\
(-1.627)\end{array}$ & $\begin{array}{c}-0.237 \\
(-0.786)\end{array}$ & $\begin{array}{c}-0.249 \\
(-1.344)\end{array}$ & $\begin{array}{c}-0.593 \\
(-1.546)\end{array}$ & $\begin{array}{c}-0.179 \\
(-0.607)\end{array}$ \\
\hline CreditRating & $\begin{array}{c}-0.0195 * * * \\
(-4.700)\end{array}$ & $\begin{array}{c}-0.0155 * * * \\
(-2.919)\end{array}$ & $\begin{array}{l}-0.0222 * * \\
(-2.478)\end{array}$ & $\begin{array}{c}-0.0196 * * * \\
(-4.863)\end{array}$ & $\begin{array}{c}-0.0167 * * * \\
(-2.993)\end{array}$ & $\begin{array}{l}-0.0214 * * \\
(-2.465)\end{array}$ \\
\hline Climate risk & $\begin{array}{c}0.00346 \\
(1.150)\end{array}$ & $\begin{array}{l}0.0148 \\
(1.146)\end{array}$ & $\begin{array}{c}-0.00272 \\
(-0.381)\end{array}$ & $\begin{array}{c}0.00385 \\
(1.299)\end{array}$ & $\begin{array}{l}0.0127 \\
(0.960)\end{array}$ & $\begin{array}{c}-0.00371 \\
(-0.536)\end{array}$ \\
\hline Climate risk*Post 2015 & $\begin{array}{l}0.00737 * * * \\
\quad(2.707)\end{array}$ & $\begin{array}{c}0.0246 * * * \\
(2.691)\end{array}$ & $\begin{array}{c}0.000849 \\
(0.171)\end{array}$ & $\begin{array}{l}0.00712 * * * \\
\quad(2.666)\end{array}$ & $\begin{array}{c}0.0243 * * * \\
(3.028)\end{array}$ & $\begin{array}{c}0.00161 \\
(0.332)\end{array}$ \\
\hline Constant & $\begin{array}{c}-4.364 * * * \\
(-4.314)\end{array}$ & $\begin{array}{c}-4.977 * * * \\
(-2.728)\end{array}$ & $\begin{array}{c}-5.043 * * * \\
(-3.486)\end{array}$ & $\begin{array}{c}-4.302 * * * \\
(-4.381)\end{array}$ & $\begin{array}{l}-4.507 * * \\
(-2.303)\end{array}$ & $\begin{array}{c}-5.106 * * * \\
(-3.821)\end{array}$ \\
\hline Observations & 4,435 & 1,528 & 1,853 & 4,326 & 1,489 & 1,817 \\
\hline R-squared & 0.768 & 0.839 & 0.683 & 0.772 & 0.844 & 0.687 \\
\hline Country Fixed Effects & Yes & Yes & Yes & Yes & Yes & Yes \\
\hline Industry Fixed Effects & Yes & Yes & Yes & Yes & Yes & Yes \\
\hline $\begin{array}{l}\text { Loan Characteristics Fixed } \\
\text { Effects }\end{array}$ & Yes & Yes & Yes & Yes & Yes & Yes \\
\hline Year Fixed Effects & Yes & Yes & Yes & Yes & Yes & Yes \\
\hline
\end{tabular}




\section{Table 6}

Climate risk and cost of bank loans.

This table presents estimates of the effects of overall climate risk on the cost of bank loans, using Log Spread as dependent variable. Columns (1) to (3) report OLS estimates on loans having a maturity of more than 3 years. Column (4) to (6) report OLS estimates on loans having a maturity of at least 5 years. Regressions (1) and (4) are conducted on the total sample. Regressions (2) and (5) cover the high-risk companies over the $60^{\text {th }}$ percentile, regressions (3) and (6) cover the low-risk companies under the $40^{\text {th }}$ percentile. All regressions include country, industry, loan characteristics (loan type, number of loans to the company on the same date, currency, loan purpose and secured/unsecured) and year fixed effects. The total sample comprises all firms in the MSCI World index from 2010 to 2018, excluding financial firms (SIC 6000-6999). Standard errors are double-clustered at the country-industry level. T-statistics are reported in parentheses. $* * *, * *$, and $*$ indicate significance at the $1 \%, 5 \%$ and $10 \%$ levels, respectively.

\begin{tabular}{|c|c|c|c|c|c|c|}
\hline VARIABLES & $\begin{array}{c}\text { (1) } \\
\text { Log Spread }\end{array}$ & $\begin{array}{c}(2) \\
\text { Log Spread }\end{array}$ & $\begin{array}{c}(3) \\
\text { Log Spread }\end{array}$ & $\begin{array}{c}(4) \\
\text { Log Spread }\end{array}$ & $\begin{array}{c}(5) \\
\text { Log Spread }\end{array}$ & $\begin{array}{c}(6) \\
\text { Log Spread }\end{array}$ \\
\hline & \multicolumn{3}{|c|}{ Maturity $>3$ years } & \multicolumn{3}{|c|}{ Maturity $>5$ years } \\
\hline & Total sample & High risk & Low risk & Total sample & High risk & Low risk \\
\hline Log Amount & $\begin{array}{c}-0.116^{* * * *} \\
(-7.618)\end{array}$ & $\begin{array}{c}-0.119 * * * \\
(-4.535)\end{array}$ & $\begin{array}{c}-0.0956 * * * \\
(-5.462)\end{array}$ & $\begin{array}{c}-0.117 * * * \\
(-7.346)\end{array}$ & $\begin{array}{c}-0.113^{* * * *} \\
(-3.993)\end{array}$ & $\begin{array}{c}-0.103 * * * \\
(-5.582)\end{array}$ \\
\hline Log Maturity & $\begin{array}{l}0.0483 \\
(0.591)\end{array}$ & $\begin{array}{l}0.257^{*} \\
(1.797)\end{array}$ & $\begin{array}{l}0.0947 \\
(0.970)\end{array}$ & $\begin{array}{c}0.337 * * \\
(2.257)\end{array}$ & $\begin{array}{c}0.693 * * * \\
(3.088)\end{array}$ & $\begin{array}{c}0.595 * * * \\
(4.552)\end{array}$ \\
\hline EBIT & $\begin{array}{c}-0.240 \\
(-0.950)\end{array}$ & $\begin{array}{c}0.266 \\
(0.837)\end{array}$ & $\begin{array}{c}-0.335 \\
(-0.733)\end{array}$ & $\begin{array}{l}0.00730 \\
(0.0292)\end{array}$ & $\begin{array}{l}0.0748 \\
(0.205)\end{array}$ & $\begin{array}{c}0.264 \\
(0.714)\end{array}$ \\
\hline LogAge & $\begin{array}{l}0.0108 \\
(0.628)\end{array}$ & $\begin{array}{l}0.0517 \\
(1.022)\end{array}$ & $\begin{array}{l}0.0127 \\
(0.746)\end{array}$ & $\begin{array}{c}0.00741 \\
(0.435)\end{array}$ & $\begin{array}{l}0.0400 \\
(0.735)\end{array}$ & $\begin{array}{c}0.00961 \\
(0.574)\end{array}$ \\
\hline Tobin Q & $\begin{array}{c}-0.0360 * \\
(-1.752)\end{array}$ & $\begin{array}{c}-0.106 * * * \\
(-3.089)\end{array}$ & $\begin{array}{c}-0.00574 \\
(-0.188)\end{array}$ & $\begin{array}{l}-0.0417 * \\
(-1.931)\end{array}$ & $\begin{array}{c}-0.0874 * * * \\
(-2.967)\end{array}$ & $\begin{array}{l}-0.0232 \\
(-0.708)\end{array}$ \\
\hline OpEx & $\begin{array}{l}-0.0329 \\
(-1.158)\end{array}$ & $\begin{array}{l}0.0533 \\
(0.518)\end{array}$ & $\begin{array}{l}-0.0590 \\
(-1.316)\end{array}$ & $\begin{array}{l}-0.0265 \\
(-0.900)\end{array}$ & $\begin{array}{l}0.000532 \\
(0.00480)\end{array}$ & $\begin{array}{l}-0.0501 \\
(-1.163)\end{array}$ \\
\hline R\&DExp & $\begin{array}{c}0.156 \\
(0.396)\end{array}$ & $\begin{array}{c}1.483 * * * \\
(3.512)\end{array}$ & $\begin{array}{c}-0.667 \\
(-1.402)\end{array}$ & $\begin{array}{c}0.182 \\
(0.487)\end{array}$ & $\begin{array}{c}1.843 * * * \\
(3.478)\end{array}$ & $\begin{array}{c}-0.591 \\
(-1.462)\end{array}$ \\
\hline Log TotAssets & $\begin{array}{l}-0.00133 \\
(-0.0768)\end{array}$ & $\begin{array}{c}-0.0497 * * \\
(-2.207)\end{array}$ & $\begin{array}{l}-0.0139 \\
(-0.410)\end{array}$ & $\begin{array}{c}0.000125 \\
(0.00732)\end{array}$ & $\begin{array}{c}-0.0583 * * \\
(-2.203)\end{array}$ & $\begin{array}{c}-0.00851 \\
(-0.275)\end{array}$ \\
\hline PPE & $\begin{array}{c}-0.00921 \\
(-0.160)\end{array}$ & $\begin{array}{l}0.0811 \\
(0.534)\end{array}$ & $\begin{array}{l}0.00115 \\
(0.0126)\end{array}$ & $\begin{array}{l}0.0378 \\
(0.646)\end{array}$ & $\begin{array}{c}0.130 \\
(0.921)\end{array}$ & $\begin{array}{c}0.0308 \\
(0.296)\end{array}$ \\
\hline CreditRating & $\begin{array}{c}-0.0104 * * * \\
(-4.141)\end{array}$ & $\begin{array}{c}-0.00744 * \\
(-1.789)\end{array}$ & $\begin{array}{c}-0.0120 * * * \\
(-2.967)\end{array}$ & $\begin{array}{c}-0.00978 * * * \\
(-3.868)\end{array}$ & $\begin{array}{c}-0.00348 \\
(-0.858)\end{array}$ & $\begin{array}{c}-0.0112 * * * \\
(-2.980)\end{array}$ \\
\hline Climate risk & $\begin{array}{c}-0.000722 \\
(-0.339)\end{array}$ & $\begin{array}{l}-0.0204 \\
(-1.322)\end{array}$ & $\begin{array}{c}-0.00620 \\
(-1.225)\end{array}$ & $\begin{array}{c}-0.00109 \\
(-0.530)\end{array}$ & $\begin{array}{l}-0.0214 \\
(-1.493)\end{array}$ & $\begin{array}{r}-0.000367 \\
(-0.0735)\end{array}$ \\
\hline Climate risk *Post 2015 & $\begin{array}{c}0.00306 \\
(1.527)\end{array}$ & $\begin{array}{c}0.0340 * * \\
(2.126)\end{array}$ & $\begin{array}{c}0.00492 \\
(1.440)\end{array}$ & $\begin{array}{c}0.00208 \\
(1.017)\end{array}$ & $\begin{array}{c}0.0393 * * \\
(2.361)\end{array}$ & $\begin{array}{c}0.000948 \\
(0.289)\end{array}$ \\
\hline Constant & $\begin{array}{c}8.155^{* * * *} \\
(23.07)\end{array}$ & $\begin{array}{l}7.332 * * * \\
(6.805)\end{array}$ & $\begin{array}{l}9.244 * * * \\
(14.77)\end{array}$ & $\begin{array}{l}6.218 * * * \\
(9.453)\end{array}$ & $\begin{array}{l}7.462 * * * \\
(6.529)\end{array}$ & $\begin{array}{l}5.881 * * * \\
(7.121)\end{array}$ \\
\hline Observations & 3,717 & 1,067 & 1,637 & 3,064 & 846 & 1,345 \\
\hline R-squared & 0.660 & 0.695 & 0.713 & 0.687 & 0.735 & 0.752 \\
\hline Country Fixed Effects & Yes & Yes & Yes & Yes & Yes & Yes \\
\hline Industry Fixed Effects & Yes & Yes & Yes & Yes & Yes & Yes \\
\hline $\begin{array}{l}\text { Loan Characteristics Fixed } \\
\text { Effects }\end{array}$ & Yes & Yes & Yes & Yes & Yes & Yes \\
\hline Year Fixed Effects & Yes & Yes & Yes & Yes & Yes & Yes \\
\hline
\end{tabular}




\section{Table 7}

Credit rating and climate risk.

This table presents estimates of the effects of overall climate risk on credit rating. Columns (1) and (2) report OLS estimates using CreditRating (credit rating) as dependent variable, for firmyear observations with a credit rating. Columns (3) and (4) report OLS estimates using No CreditRating (a dummy equal to 1 for firm-year observations without credit rating) as dependent variable. Columns (5) to (7) report OLS estimates using, respectively, Grade Variation (a dummy equal to 1 if CreditRating is different from the lagged value of CreditRating), Downgrade (a dummy equal to 1 if CreditRating is lower than the lagged value of CreditRating) and Upgrade (a dummy equal to 1 if CreditRating is higher than the lagged value of CreditRating) as dependent variables. All regressions include country-industry and year fixed effects and exclude observations with missing Log IntCoverage. See Appendix A for variable definitions and Appendix B for details regarding the variable CreditRating. The sample comprises all firms in the MSCI World index from 2010 to 2018, excluding financial firms (SIC 6000-6999). Standard errors are clustered at the firm level. T-statistics are reported in parentheses. ***, **, and * indicate significance at the $1 \%, 5 \%$ and $10 \%$ levels, respectively.

\begin{tabular}{|c|c|c|c|c|c|c|c|}
\hline VARIABLES & $\begin{array}{c}\text { (1) } \\
\text { CreditRating }\end{array}$ & $\begin{array}{c}(2) \\
\text { CreditRating }\end{array}$ & $\begin{array}{c}\text { (3) } \\
\text { No } \\
\text { CreditRating } \\
\end{array}$ & $\begin{array}{c}\text { (4) } \\
\text { No } \\
\text { CreditRating } \\
\end{array}$ & $\begin{array}{c}(5) \\
\text { Grade } \\
\text { variation } \\
\end{array}$ & $\begin{array}{c}(6) \\
\text { Downgrade }\end{array}$ & $\begin{array}{c}(7) \\
\text { Upgrade }\end{array}$ \\
\hline EBIT & $\begin{array}{c}13.49 * * * \\
(7.020)\end{array}$ & $\begin{array}{c}13.48 * * * \\
(7.016)\end{array}$ & $\begin{array}{l}-0.304^{*} \\
(-1.888)\end{array}$ & $\begin{array}{l}-0.305 * \\
(-1.894)\end{array}$ & $\begin{array}{c}-0.626 * * * \\
(-4.006)\end{array}$ & $\begin{array}{c}-0.711 * * * \\
(-6.091)\end{array}$ & $\begin{array}{l}0.0854 \\
(0.766)\end{array}$ \\
\hline Log Age & $\begin{array}{c}0.430 * * * \\
(3.619)\end{array}$ & $\begin{array}{c}0.430 * * * \\
(3.619)\end{array}$ & $\begin{array}{c}-0.0577 * * * \\
(-4.754)\end{array}$ & $\begin{array}{c}-0.0577 * * * \\
(-4.752)\end{array}$ & $\begin{array}{c}-0.0266 * * * \\
(-3.027)\end{array}$ & $\begin{array}{c}0.0130 * * \\
(2.452)\end{array}$ & $\begin{array}{c}-0.0396 * * * \\
(-5.198)\end{array}$ \\
\hline TobinQ & $\begin{array}{c}0.131 \\
(1.072)\end{array}$ & $\begin{array}{c}0.133 \\
(1.084)\end{array}$ & $\begin{array}{c}0.0340 * * * \\
(3.852)\end{array}$ & $\begin{array}{c}0.0341 * * * \\
(3.858)\end{array}$ & $\begin{array}{c}0.00902 \\
(0.826)\end{array}$ & $\begin{array}{c}0.00715 \\
(1.137)\end{array}$ & $\begin{array}{c}0.00187 \\
(0.203)\end{array}$ \\
\hline OpEx & $\begin{array}{c}0.305 \\
(1.111)\end{array}$ & $\begin{array}{c}0.305 \\
(1.112)\end{array}$ & $\begin{array}{c}-0.0443^{*} \\
(-1.741)\end{array}$ & $\begin{array}{c}-0.0443^{*} \\
(-1.740)\end{array}$ & $\begin{array}{c}-0.0414 * * \\
(-2.098)\end{array}$ & $\begin{array}{c}-0.0289 * * \\
(-2.439)\end{array}$ & $\begin{array}{l}-0.0125 \\
(-0.760)\end{array}$ \\
\hline R\&DExp & $\begin{array}{c}-6.582 \\
(-1.639)\end{array}$ & $\begin{array}{c}-6.551 \\
(-1.628)\end{array}$ & $\begin{array}{c}0.519 \\
(1.506)\end{array}$ & $\begin{array}{c}0.522 \\
(1.515)\end{array}$ & $\begin{array}{c}-0.243 \\
(-0.846)\end{array}$ & $\begin{array}{c}-0.227 \\
(-1.375)\end{array}$ & $\begin{array}{c}-0.0160 \\
(-0.0726)\end{array}$ \\
\hline Log TotAssets & $\begin{array}{c}0.871 * * * \\
(6.494)\end{array}$ & $\begin{array}{c}0.872 * * * \\
(6.480)\end{array}$ & $\begin{array}{c}-0.0963 * * * \\
(-8.410)\end{array}$ & $\begin{array}{c}-0.0962 * * * \\
(-8.387)\end{array}$ & $\begin{array}{c}0.0192 * * \\
(2.092)\end{array}$ & $\begin{array}{c}0.00657 \\
(1.157)\end{array}$ & $\begin{array}{c}0.0126^{*} \\
(1.816)\end{array}$ \\
\hline PPE & $\begin{array}{c}0.270 \\
(0.358)\end{array}$ & $\begin{array}{c}0.267 \\
(0.354)\end{array}$ & $\begin{array}{l}0.0244 \\
(0.313)\end{array}$ & $\begin{array}{l}0.0240 \\
(0.307)\end{array}$ & $\begin{array}{c}0.00656 \\
(0.120)\end{array}$ & $\begin{array}{l}0.000323 \\
(0.00860)\end{array}$ & $\begin{array}{c}0.00623 \\
(0.135)\end{array}$ \\
\hline Log IntCoverage & $\begin{array}{c}-1.644 \\
(-0.247)\end{array}$ & $\begin{array}{c}-1.673 \\
(-0.251)\end{array}$ & $\begin{array}{c}1.442 * * * \\
(3.740)\end{array}$ & $\begin{array}{c}1.438 * * * \\
(3.726)\end{array}$ & $\begin{array}{c}0.148 \\
(0.201)\end{array}$ & $\begin{array}{c}0.330 \\
(0.766)\end{array}$ & $\begin{array}{c}-0.182 \\
(-0.318)\end{array}$ \\
\hline WorkingCap & $\begin{array}{l}1.606^{*} \\
(1.790)\end{array}$ & $\begin{array}{l}1.597 * \\
(1.783)\end{array}$ & $\begin{array}{l}0.202 * * \\
(2.378)\end{array}$ & $\begin{array}{l}0.202 * * \\
(2.371)\end{array}$ & $\begin{array}{l}0.0652 \\
(0.969)\end{array}$ & $\begin{array}{l}0.0350 \\
(0.847)\end{array}$ & $\begin{array}{l}0.0302 \\
(0.547)\end{array}$ \\
\hline Climate risk & $\begin{array}{c}0.00410 \\
(0.224)\end{array}$ & $\begin{array}{c}0.00240 \\
(0.126)\end{array}$ & $\begin{array}{c}-0.00116 \\
(-0.629)\end{array}$ & $\begin{array}{c}-0.00140 \\
(-0.745)\end{array}$ & $\begin{array}{c}-0.000306 \\
(-0.235)\end{array}$ & $\begin{array}{l}-1.37 \mathrm{e}-05 \\
(-0.0168)\end{array}$ & $\begin{array}{c}-0.000292 \\
(-0.281)\end{array}$ \\
\hline Climate risk*Post 2015 & & $\begin{array}{c}0.00451 \\
(0.492)\end{array}$ & & $\begin{array}{c}0.000704 \\
(1.010)\end{array}$ & $\begin{array}{l}-7.76 \mathrm{e}-05 \\
(-0.0659)\end{array}$ & $\begin{array}{c}-0.000845 \\
(-1.054)\end{array}$ & $\begin{array}{c}0.000768 \\
(0.865)\end{array}$ \\
\hline Constant & $\begin{array}{c}-0.811 \\
(-0.497)\end{array}$ & $\begin{array}{c}-0.808 \\
(-0.496)\end{array}$ & $\begin{array}{c}1.614 * * * \\
(10.37)\end{array}$ & $\begin{array}{c}1.613 * * * \\
(10.36)\end{array}$ & $\begin{array}{l}-0.165 \\
(-1.340)\end{array}$ & $\begin{array}{l}0.0670 \\
(0.869)\end{array}$ & $\begin{array}{c}-0.232 * * \\
(-2.376)\end{array}$ \\
\hline $\begin{array}{l}\text { Observations } \\
\text { R-squared } \\
\text { Country-Industry } \\
\text { Fixed Effects } \\
\text { Year Fixed Effects }\end{array}$ & $\begin{array}{c}6,758 \\
0.329 \\
\text { Yes }\end{array}$ & $\begin{array}{c}6,758 \\
0.329 \\
\text { Yes }\end{array}$ & $\begin{array}{c}9,957 \\
0.549 \\
\text { Yes }\end{array}$ & $\begin{array}{c}9,957 \\
0.549 \\
\text { Yes }\end{array}$ & $\begin{array}{c}6,070 \\
0.121 \\
\text { Yes }\end{array}$ & $\begin{array}{c}6,070 \\
0.085 \\
\text { Yes }\end{array}$ & $\begin{array}{c}6,070 \\
0.106 \\
\text { Yes }\end{array}$ \\
\hline
\end{tabular}




\section{Table 8}

Difference-in-differences in leverage around the year 2015

This table presents difference-in-differences estimates for the book leverage before and after the year 2015. Columns (1) to (8) report OLS estimates using dummy variables equal to 1 if the climate indicator risk is above the $60^{\text {th }}$ percentile and 0 if the climate risk indicator is below the $40^{\text {th }}$ percentile, and the dummy variables interacted with Post2015, as independent variables. The regressions are conducted on all firm-year observations except those between the $40^{\text {th }}$ and the $60^{\text {th }}$ percentiles of the climate risk indicator. Column (1) uses the overall climate risk, columns (2) to (8) are constructed using subrisk indicators, Droughts, Heatwaves, Storms, Heavy rainfall, Temperature rise, Rainfall patterns and Sea level rise, respectively. All regressions include country-industry and year fixed effects. See Appendix A for variable definitions. The sample comprises all firms in the MSCI World index from 2010 to 2018, excluding financial firms (SIC 6000-6999). Standard errors are clustered at the firm level. T-statistics are reported in parentheses. ${ }^{* *},{ }^{* *}$, and $*$ indicate significance at the $1 \%, 5 \%$ and $10 \%$ levels, respectively.

\begin{tabular}{|c|c|c|c|c|c|c|c|c|}
\hline VARIABLES & $\begin{array}{c}(1) \\
\text { BookLev } \\
\end{array}$ & $\begin{array}{c}(2) \\
\text { BookLev } \\
\end{array}$ & $\begin{array}{c}(3) \\
\text { BookLev } \\
\end{array}$ & $\begin{array}{c}(4) \\
\text { BookLev } \\
\end{array}$ & $\begin{array}{c}(5) \\
\text { BookLev } \\
\end{array}$ & $\begin{array}{c}(6) \\
\text { BookLev } \\
\end{array}$ & $\begin{array}{c}(7) \\
\text { BookLev } \\
\end{array}$ & $\begin{array}{c}(8) \\
\text { BookLev } \\
\end{array}$ \\
\hline EBIT & $\begin{array}{c}-0.172 * * * \\
(-2.587)\end{array}$ & $\begin{array}{c}-0.176 * * * \\
(-2.625)\end{array}$ & $\begin{array}{c}-0.188 * * * \\
(-2.612)\end{array}$ & $\begin{array}{c}-0.175 * * * \\
(-2.658)\end{array}$ & $\begin{array}{c}-0.216 * * * \\
(-3.047)\end{array}$ & $\begin{array}{c}-0.173 * * * \\
(-2.649)\end{array}$ & $\begin{array}{c}-0.141 * * \\
(-2.201)\end{array}$ & $\begin{array}{c}-0.138 * * \\
(-2.319)\end{array}$ \\
\hline Log Age & $\begin{array}{c}0.000445 \\
(0.103)\end{array}$ & $\begin{array}{c}0.00284 \\
(0.698)\end{array}$ & $\begin{array}{c}-0.000695 \\
(-0.166)\end{array}$ & $\begin{array}{c}-0.000536 \\
(-0.117)\end{array}$ & $\begin{array}{c}0.00102 \\
(0.250)\end{array}$ & $\begin{array}{c}-0.000742 \\
(-0.187)\end{array}$ & $\begin{array}{c}-0.000520 \\
(-0.126)\end{array}$ & $\begin{array}{c}-0.00206 \\
(-0.496)\end{array}$ \\
\hline TobinQ & $\begin{array}{c}-0.00396 \\
(-1.153)\end{array}$ & $\begin{array}{c}-0.00322 \\
(-0.916)\end{array}$ & $\begin{array}{c}-0.00302 \\
(-0.803)\end{array}$ & $\begin{array}{c}-0.00155 \\
(-0.419)\end{array}$ & $\begin{array}{c}-0.00179 \\
(-0.447)\end{array}$ & $\begin{array}{c}-0.00257 \\
(-0.727)\end{array}$ & $\begin{array}{c}-0.00253 \\
(-0.700)\end{array}$ & $\begin{array}{c}-0.00329 \\
(-1.023)\end{array}$ \\
\hline OpEx & $\begin{array}{c}-0.0301 * * \\
(-2.196)\end{array}$ & $\begin{array}{c}-0.0297 * * \\
(-2.185)\end{array}$ & $\begin{array}{c}-0.0381 * * * \\
(-2.832)\end{array}$ & $\begin{array}{c}-0.0373 * * * \\
(-2.743)\end{array}$ & $\begin{array}{l}-0.0263^{*} \\
(-1.916)\end{array}$ & $\begin{array}{c}-0.0389 * * * \\
(-3.198)\end{array}$ & $\begin{array}{c}-0.0379 * * * \\
(-2.972)\end{array}$ & $\begin{array}{c}-0.0304 * * \\
(-2.422)\end{array}$ \\
\hline R\&DExp & $\begin{array}{c}-0.670 * * * \\
(-5.718)\end{array}$ & $\begin{array}{c}-0.669 * * * \\
(-5.364)\end{array}$ & $\begin{array}{c}-0.579 * * * \\
(-4.515)\end{array}$ & $\begin{array}{c}-0.581 * * * \\
(-4.729)\end{array}$ & $\begin{array}{c}-0.568 * * * \\
(-4.470)\end{array}$ & $\begin{array}{c}-0.606 * * * \\
(-4.701)\end{array}$ & $\begin{array}{c}-0.738 * * * \\
(-6.028)\end{array}$ & $\begin{array}{c}-0.625 * * * \\
(-5.235)\end{array}$ \\
\hline Log TotAssets & $\begin{array}{r}0.00517 \\
(1.145)\end{array}$ & $\begin{array}{c}0.00154 \\
(0.345)\end{array}$ & $\begin{array}{c}0.000235 \\
(0.0538)\end{array}$ & $\begin{array}{c}0.00202 \\
(0.437)\end{array}$ & $\begin{array}{r}0.00467 \\
(1.027)\end{array}$ & $\begin{array}{c}-0.00243 \\
(-0.547)\end{array}$ & $\begin{array}{c}0.00225 \\
(0.478)\end{array}$ & $\begin{array}{c}0.00476 \\
(1.064)\end{array}$ \\
\hline PPE & $\begin{array}{c}0.133 * * * \\
(3.384)\end{array}$ & $\begin{array}{c}0.137 * * * \\
(3.479)\end{array}$ & $\begin{array}{c}0.0930 * * \\
(2.261)\end{array}$ & $\begin{array}{c}0.0866^{* * *} \\
(2.266)\end{array}$ & $\begin{array}{c}0.100 * * * \\
(2.739)\end{array}$ & $\begin{array}{c}0.0856^{* * * *} \\
(2.720)\end{array}$ & $\begin{array}{c}0.124 * * * \\
(3.302)\end{array}$ & $\begin{array}{c}0.132 * * * \\
(3.478)\end{array}$ \\
\hline CreditRating & $\begin{array}{c}0.00198 * * * \\
(3.011)\end{array}$ & $\begin{array}{c}0.00145^{* *} \\
(2.302)\end{array}$ & $\begin{array}{c}0.00178 * * * \\
(2.635)\end{array}$ & $\begin{array}{c}0.00244 * * * \\
(3.490)\end{array}$ & $\begin{array}{c}0.00218 * * * \\
(3.225)\end{array}$ & $\begin{array}{c}0.00235^{* * *} * \\
(3.612)\end{array}$ & $\begin{array}{c}0.00214 * * * \\
(3.142)\end{array}$ & $\begin{array}{c}0.00173^{* * * *} \\
(2.685)\end{array}$ \\
\hline HighClimateRisk & $\begin{array}{l}-0.0227 \\
(-1.448)\end{array}$ & & & & & & & \\
\hline HighClimateRisk $*$ Post 2015 & $\begin{array}{c}-0.0209 * * * \\
(-3.750)\end{array}$ & & & & & & & \\
\hline HighDroughts & & $\begin{array}{c}-0.00841 \\
(-0.513)\end{array}$ & & & & & & \\
\hline HighDroughts*Post 2015 & & $\begin{array}{c}-0.0228 * * * \\
(-4.079)\end{array}$ & & & & & & \\
\hline HighHeatwaves & & & $\begin{array}{l}-0.0133 \\
(-0.993)\end{array}$ & & & & & \\
\hline HighHeatwaves*Post2015 & & & $\begin{array}{c}-0.0198 * * * \\
(-3.435)\end{array}$ & & & & & \\
\hline HighStorms & & & & $\begin{array}{l}-0.0137 \\
(-0.832)\end{array}$ & & & & \\
\hline HighStorms*Post 2015 & & & & $\begin{array}{c}-0.0181^{* * *} * \\
(-3.129)\end{array}$ & & & & \\
\hline HighHeavyrainfall & & & & & $\begin{array}{l}0.0117 \\
(0.824)\end{array}$ & & & \\
\hline HighHeavyrainfall*Post 2015 & & & & & $\begin{array}{c}-0.0287 * * * \\
(-4.942)\end{array}$ & & & \\
\hline HighTemperaturerise & & & & & & $\begin{array}{c}0.00392 \\
(0.331)\end{array}$ & & \\
\hline HighTemperaturerise ${ }^{*}$ Post 2015 & & & & & & $\begin{array}{c}0.00460 \\
(0.800)\end{array}$ & & \\
\hline HighRainfallpatterns & & & & & & & $\begin{array}{c}-0.00919 \\
(-0.793)\end{array}$ & \\
\hline HighRainfallpatterns*Post2015 & & & & & & & $\begin{array}{c}-0.00880 \\
(-1.575)\end{array}$ & \\
\hline HighSealevelrise & & & & & & & & -0.0229 \\
\hline
\end{tabular}




\begin{tabular}{|c|c|c|c|c|c|c|c|c|}
\hline HighSealevelrise*Post 2015 & & & & & & & & $\begin{array}{c}(-1.635) \\
-0.0159 * * * \\
(-2.851)\end{array}$ \\
\hline Constant & $\begin{array}{c}0.141 \\
(1.598)\end{array}$ & $\begin{array}{c}0.445 * * * \\
(7.016)\end{array}$ & $\begin{array}{l}0.203^{*} \\
(1.898)\end{array}$ & $\begin{array}{c}-0.405 * * * \\
(-3.037)\end{array}$ & $\begin{array}{c}-0.527 * * * \\
(-4.707)\end{array}$ & $\begin{array}{c}0.161 * * \\
(2.023)\end{array}$ & $\begin{array}{c}0.155^{* * *} * \\
(2.687)\end{array}$ & $\begin{array}{c}0.442 * * * \\
(3.075)\end{array}$ \\
\hline Observations & 8,192 & 8,193 & 8,201 & 8,181 & 8,197 & 8,206 & 8,175 & 8,155 \\
\hline R-squared & 0.536 & 0.563 & 0.523 & 0.512 & 0.524 & 0.537 & 0.533 & 0.556 \\
\hline Country-Industry Fixed Effects & Yes & Yes & Yes & Yes & Yes & Yes & Yes & Yes \\
\hline Year Fixed Effects & Yes & Yes & Yes & Yes & Yes & Yes & Yes & Yes \\
\hline
\end{tabular}




\section{Table 9}

Climate risk, long-term debt and corporate social responsibility (CSR).

Panel A reports estimates of the effects of overall climate risk on long-term debt, after controlling for CSR. Columns (1) to (4) report OLS estimates conducted on the total sample, using Overall CSR Score, Environment Score, CDP answer, A list, respectively, as our measures of CSR. Panel B reports estimates of the effects of overall climate risk on long-term debt, when analyzing subsamples based on the values of CSR variables. Columns (1) and (2), (3) and (4), (5) and (6), (7) and (8) report OLS estimates conducted on subsamples constructed based on the values of Overall CSR Score, Environment Score, CDP answer, A list, respectively. All regressions include country-industry and year fixed effects. The sample comprises all firms in the MSCI World index from 2010 to 2018, excluding financial firms (SIC 6000-6999). Standard errors are clustered at the firm level. T-statistics are reported in parentheses. ***, **, and * indicate significance at the $1 \%, 5 \%$ and $10 \%$ levels, respectively.

Panel A. Climate risk and long-term debt, after controlling for CSR

\begin{tabular}{|c|c|c|c|c|}
\hline VARIABLES & $\begin{array}{c}(1) \\
\text { BookLev } \\
\end{array}$ & $\begin{array}{c}(2) \\
\text { BookLev } \\
\end{array}$ & $\begin{array}{c}(3) \\
\text { BookLev } \\
\end{array}$ & $\begin{array}{c}(4) \\
\text { BookLev } \\
\end{array}$ \\
\hline EBIT & $\begin{array}{c}-0.185 * * * \\
(-2.756)\end{array}$ & $\begin{array}{c}-0.185 * * * \\
(-2.765)\end{array}$ & $\begin{array}{c}-0.115 \\
(-1.435)\end{array}$ & $\begin{array}{c}-0.117 \\
(-1.465)\end{array}$ \\
\hline Log Age & $\begin{array}{c}-0.00605 \\
(-1.506)\end{array}$ & $\begin{array}{c}-0.00603 \\
(-1.499)\end{array}$ & $\begin{array}{c}0.000773 \\
(0.167)\end{array}$ & $\begin{array}{c}0.000707 \\
(0.152)\end{array}$ \\
\hline TobinQ & $\begin{array}{c}-0.00192 \\
(-0.505)\end{array}$ & $\begin{array}{c}-0.00196 \\
(-0.517)\end{array}$ & $\begin{array}{c}-0.00244 \\
(-0.558)\end{array}$ & $\begin{array}{c}-0.00229 \\
(-0.522)\end{array}$ \\
\hline OpEx & $\begin{array}{c}-0.0413 * * * \\
(-3.415)\end{array}$ & $\begin{array}{c}-0.0418 * * * \\
(-3.453)\end{array}$ & $\begin{array}{c}-0.0387 * * \\
(-2.243)\end{array}$ & $\begin{array}{c}-0.0390 * * \\
(-2.266)\end{array}$ \\
\hline R\&DExp & $\begin{array}{c}-0.507 * * * \\
(-3.871)\end{array}$ & $\begin{array}{c}-0.521 * * * \\
(-4.011)\end{array}$ & $\begin{array}{c}-0.460 * * * \\
(-3.390)\end{array}$ & $\begin{array}{c}-0.463 * * * \\
(-3.412)\end{array}$ \\
\hline LogTotalAssets & $\begin{array}{c}-0.000104 \\
(-0.0241)\end{array}$ & $\begin{array}{c}-0.000360 \\
(-0.0821)\end{array}$ & $\begin{array}{c}-0.00342 \\
(-0.675)\end{array}$ & $\begin{array}{c}-0.00342 \\
(-0.681)\end{array}$ \\
\hline PPE & $\begin{array}{c}0.0973 * * * \\
(3.043)\end{array}$ & $\begin{array}{c}0.0964 * * * \\
(3.015)\end{array}$ & $\begin{array}{c}0.0702 * \\
(1.913)\end{array}$ & $\begin{array}{c}0.0696^{*} \\
(1.903)\end{array}$ \\
\hline CreditRating & $\begin{array}{c}0.00169 \text { *** } \\
(2.782)\end{array}$ & $\begin{array}{c}0.00164 * * * \\
(2.712)\end{array}$ & $\begin{array}{c}0.00164 * * \\
(2.535)\end{array}$ & $\begin{array}{c}0.00163^{* *} \\
(2.519)\end{array}$ \\
\hline Overall CSR Score & $\begin{array}{r}-0.00267 \\
(-1.368)\end{array}$ & & & \\
\hline Environment Score & & $\begin{array}{c}-0.000489 \\
(-0.348)\end{array}$ & & \\
\hline CDP answer & & & $\begin{array}{c}-0.00548 \\
(-0.775)\end{array}$ & \\
\hline A list & & & & $\begin{array}{c}-0.00553 \\
(-0.934)\end{array}$ \\
\hline Climate risk & $\begin{array}{c}-0.00107 \\
(-1.527)\end{array}$ & $\begin{array}{r}-0.00107 \\
(-1.516)\end{array}$ & $\begin{array}{c}-0.000307 \\
(-0.370)\end{array}$ & $\begin{array}{c}-0.000310 \\
(-0.374)\end{array}$ \\
\hline Climate risk*Post2015 & $\begin{array}{c}-0.00134 * * * \\
(-5.337)\end{array}$ & $\begin{array}{c}-0.00134 * * * \\
(-5.324)\end{array}$ & $\begin{array}{c}-0.00193 * * * * \\
(-4.959)\end{array}$ & $\begin{array}{c}-0.00193 * * * \\
(-4.909)\end{array}$ \\
\hline Constant & 0.543 & 0.548 & $\begin{array}{c}-0.819 * * * \\
(-6.988)\end{array}$ & $\begin{array}{c}-0.816^{* * *} \\
(-6.976)\end{array}$ \\
\hline Observations & 8,598 & 8,598 & 5,790 & 5,790 \\
\hline R-squared & 0.527 & 0.526 & 0.534 & 0.534 \\
\hline Country-Industry Fixed Effects & Yes & Yes & Yes & Yes \\
\hline Year Fixed Effects & Yes & Yes & Yes & Yes \\
\hline
\end{tabular}


Panel B. Climate risk and long-term debt, subsamples based on CSR variables

\begin{tabular}{|c|c|c|c|c|c|c|c|c|}
\hline VARIABLES & $\begin{array}{c}(1) \\
\text { BookLev } \\
\end{array}$ & $\begin{array}{c}(2) \\
\text { BookLev } \\
\end{array}$ & $\begin{array}{c}(3) \\
\text { BookLev } \\
\end{array}$ & $\begin{array}{c}(4) \\
\text { BookLev } \\
\end{array}$ & $\begin{array}{c}5) \\
\text { BookLev }\end{array}$ & $\begin{array}{c}(6) \\
\text { BookLev } \\
\end{array}$ & $\begin{array}{c}(7) \\
\text { BookLev } \\
\end{array}$ & $\begin{array}{c}(8) \\
\text { BookLev } \\
\end{array}$ \\
\hline & $\begin{array}{c}\text { Overall CSR } \\
\text { Score above } \\
\text { median }\end{array}$ & $\begin{array}{c}\text { Overall CSR } \\
\text { Score below } \\
\text { median }\end{array}$ & $\begin{array}{c}\text { Environment } \\
\text { Score above } \\
\text { median }\end{array}$ & $\begin{array}{c}\text { Environment } \\
\text { Score below } \\
\text { median }\end{array}$ & $\begin{array}{l}\text { Answer to } \\
\text { CDP }\end{array}$ & $\begin{array}{c}\text { No answer to } \\
\text { CDP }\end{array}$ & $\begin{array}{c}\text { In CDP's A } \\
\text { list }\end{array}$ & $\begin{array}{c}\text { Not in CDP's } \\
\text { A list }\end{array}$ \\
\hline EBIT & $\begin{array}{c}-0.191 * * \\
(-2.328)\end{array}$ & $\begin{array}{c}-0.120 \\
(-1.407)\end{array}$ & $\begin{array}{c}-0.131 \\
(-1.502)\end{array}$ & $\begin{array}{l}-0.190 * * \\
(-2.235)\end{array}$ & $\begin{array}{c}-0.246 * * \\
(-2.531)\end{array}$ & $\begin{array}{c}0.163 \\
(1.183)\end{array}$ & $\begin{array}{c}-0.228 \\
(-1.398)\end{array}$ & $\begin{array}{c}-0.121 \\
(-1.457)\end{array}$ \\
\hline Log Age & $\begin{array}{c}-0.00479 \\
(-0.967)\end{array}$ & $\begin{array}{c}-0.00878 \\
(-1.624)\end{array}$ & $\begin{array}{c}0.000237 \\
(0.0438)\end{array}$ & $\begin{array}{c}-0.00937 * \\
(-1.876)\end{array}$ & $\begin{array}{c}0.00450 \\
(0.823)\end{array}$ & $\begin{array}{l}-0.0108 \\
(-1.311)\end{array}$ & $\begin{array}{l}0.0149 \\
(1.571)\end{array}$ & $\begin{array}{c}-0.00207 \\
(-0.431)\end{array}$ \\
\hline TobinQ & $\begin{array}{c}-0.00237 \\
(-0.505)\end{array}$ & $\begin{array}{l}-0.00197 \\
(-0.393)\end{array}$ & $\begin{array}{l}-0.00115 \\
(-0.251)\end{array}$ & $\begin{array}{c}-0.00293 \\
(-0.609)\end{array}$ & $\begin{array}{c}0.00318 \\
(0.561)\end{array}$ & $\begin{array}{c}-0.00902 \\
(-1.542)\end{array}$ & $\begin{array}{l}0.0150 \\
(1.212)\end{array}$ & $\begin{array}{c}-0.00273 \\
(-0.595)\end{array}$ \\
\hline OpEx & $\begin{array}{c}-0.0445 * * * \\
(-3.109)\end{array}$ & $\begin{array}{c}-0.0299 * \\
(-1.893)\end{array}$ & $\begin{array}{c}-0.0391 * * \\
(-2.533)\end{array}$ & $\begin{array}{c}-0.0453 * * * \\
(-3.245)\end{array}$ & $\begin{array}{c}-0.0353^{*} \\
(-1.917)\end{array}$ & $\begin{array}{l}-0.0296 \\
(-1.198)\end{array}$ & $\begin{array}{c}-0.00758 \\
(-0.306)\end{array}$ & $\begin{array}{c}-0.0369 * * \\
(-1.993)\end{array}$ \\
\hline R\&DExp & $\begin{array}{c}-0.430 * * * \\
(-2.593)\end{array}$ & $\begin{array}{c}-0.569 * * * \\
(-3.540)\end{array}$ & $\begin{array}{c}-0.486 * * * \\
(-3.091)\end{array}$ & $\begin{array}{c}-0.608 * * * \\
(-3.886)\end{array}$ & $\begin{array}{c}-0.474 * * * \\
(-2.884)\end{array}$ & $\begin{array}{c}-0.450 * * \\
(-2.474)\end{array}$ & $\begin{array}{c}-0.162 \\
(-0.865)\end{array}$ & $\begin{array}{c}-0.529 * * * \\
(-3.581)\end{array}$ \\
\hline LogTotalAssets & $\begin{array}{c}-0.000603 \\
(-0.123)\end{array}$ & $\begin{array}{c}-0.00111 \\
(-0.191)\end{array}$ & $\begin{array}{c}-0.00300 \\
(-0.543)\end{array}$ & $\begin{array}{c}0.00134 \\
(0.248)\end{array}$ & $\begin{array}{c}-0.00258 \\
(-0.422)\end{array}$ & $\begin{array}{c}-0.00413 \\
(-0.425)\end{array}$ & $\begin{array}{c}-0.00195 \\
(-0.188)\end{array}$ & $\begin{array}{c}-0.00305 \\
(-0.560)\end{array}$ \\
\hline PPE & $\begin{array}{c}0.174 * * * \\
(3.912)\end{array}$ & $\begin{array}{l}0.0284 \\
(0.744)\end{array}$ & $\begin{array}{c}0.186 * * * \\
(4.538)\end{array}$ & $\begin{array}{c}0.00863 \\
(0.199)\end{array}$ & $\begin{array}{l}0.0750 * \\
(1.653)\end{array}$ & $\begin{array}{l}-0.0440 \\
(-0.686)\end{array}$ & $\begin{array}{c}0.148 * * \\
(2.010)\end{array}$ & $\begin{array}{c}0.0628 * \\
(1.679)\end{array}$ \\
\hline CreditRating & $\begin{array}{c}0.000882 \\
(1.300)\end{array}$ & $\begin{array}{c}0.00261 * * * \\
(2.893)\end{array}$ & $\begin{array}{c}0.00100 \\
(1.294)\end{array}$ & $\begin{array}{c}0.00192 * * \\
(2.330)\end{array}$ & $\begin{array}{c}0.000697 \\
(1.020)\end{array}$ & $\begin{array}{c}0.00498 * * * \\
(3.115)\end{array}$ & $\begin{array}{c}0.000753 \\
(0.727)\end{array}$ & $\begin{array}{c}0.00168 * * \\
(2.398)\end{array}$ \\
\hline Climate risk & $\begin{array}{r}-0.00111 \\
(-1.377)\end{array}$ & $\begin{array}{c}-0.00143 \\
(-1.505)\end{array}$ & $\begin{array}{c}-0.000622 \\
(-0.751)\end{array}$ & $\begin{array}{c}-0.00145 \\
(-1.518)\end{array}$ & $\begin{array}{c}-0.000189 \\
(-0.202)\end{array}$ & $\begin{array}{c}-0.000372 \\
(-0.244)\end{array}$ & $\begin{array}{c}-0.000754 \\
(-0.550)\end{array}$ & $\begin{array}{c}-0.000169 \\
(-0.193)\end{array}$ \\
\hline Climate risk $*$ Post 2015 & $\begin{array}{c}-0.000582^{*} \\
(-1.664)\end{array}$ & $\begin{array}{c}-0.00171 * * * \\
(-4.647)\end{array}$ & $\begin{array}{c}-0.00161 * * * \\
(-4.368)\end{array}$ & $\begin{array}{c}-0.000946^{* *} \\
(-2.178)\end{array}$ & $\begin{array}{c}-0.00155^{* * *} \\
(-4.253)\end{array}$ & $\begin{array}{c}-0.00475^{* * *} * \\
(-3.992)\end{array}$ & $\begin{array}{c}-0.000591 \\
(-0.863)\end{array}$ & $\begin{array}{c}-0.00245^{* * * *} \\
(-5.269)\end{array}$ \\
\hline Constant & $\begin{array}{c}0.331^{* * *} \\
(3.414)\end{array}$ & $\begin{array}{c}0.667 * * * \\
(6.849)\end{array}$ & $\begin{array}{c}0.842 * * * \\
(9.166)\end{array}$ & $\begin{array}{c}0.160 \\
(1.471)\end{array}$ & $\begin{array}{l}-0.00909 \\
(-0.0923)\end{array}$ & $\begin{array}{c}0.717 * * * \\
(4.919)\end{array}$ & $\begin{array}{l}-0.0250 \\
(-0.144)\end{array}$ & $\begin{array}{c}0.553 * * * \\
(4.241)\end{array}$ \\
\hline Observations & 3,875 & 4,723 & 4,200 & 4,398 & 4,467 & 1,323 & 889 & 4,901 \\
\hline R-squared & 0.632 & 0.544 & 0.579 & 0.539 & 0.561 & 0.634 & 0.687 & 0.543 \\
\hline $\begin{array}{l}\text { Country-Industry Fixed } \\
\text { Effects }\end{array}$ & Yes & Yes & Yes & Yes & Yes & Yes & Yes & Yes \\
\hline Year Fixed Effects & Yes & Yes & Yes & Yes & Yes & Yes & Yes & Yes \\
\hline
\end{tabular}




\section{Appendix A. Variable Definitions}

\begin{tabular}{|c|c|}
\hline Variable & Description \\
\hline A list & Equals one if the company is rated A by CDP. Set to missing if the company was not questioned by CDP \\
\hline BookLev & Ratio of long-term debt to book assets. DLTT/AT in Compustat \\
\hline CDP answer & Equals one if the company has answered to the CDP questionnaire in a sufficient manner, such that CDP is able to give a rating \\
\hline Climate risk & CRIS global risk grade for median scenario, 2050 time-horizon. Source Carbone 4, March 2018. \\
\hline CreditRating & $\begin{array}{l}\text { This variable is based on S\&P Long-term Issuer Rating when available. If not available, we rely on Moody's Long-term Issuer Rating; and eventually on Fitch } \\
\text { Long-term Issuer Default Rating if both measures are not available. Similar to Baghai et al. (2014), we linearize these ratings from } 1 \text { to } 20 \text {. Missing ratings are } \\
\text { coded 0. See Appendix B for more details }\end{array}$ \\
\hline Downgrade & Equals one if CreditRating is lower than the lagged value of CreditRating. Set to missing if CreditRating or its lagged value are missing \\
\hline Droughts & CRIS drought risk grade for median scenario, 2050 time-horizon. Source Carbone 4, March 2018. \\
\hline EBIT & Ratio of EBIT to book assets. EBIT/AT in Compustat \\
\hline Environment Score & Environmental pillar score given in MSCI IVA ratings \\
\hline Grade variation & Equals one if the credit rating (CreditRating) is different from the lagged value of the credit rating. Set to missing if CreditRating or its lagged value are missing \\
\hline Heavy rainfall & CRIS heavy rainfall risk grade for median scenario, 2050 time-horizon. Source Carbone 4, March 2018. \\
\hline Heat waves & CRIS heat wave risk grade for median scenario, 2050 time-horizon. Source Carbone 4, March 2018. \\
\hline HighClimateRisk & Equals one for firms having Climate risk above the $60^{\text {th }}$ percentile, 0 for firms below the $40^{\text {th }}$ percentile. Set to missing between the $40^{\text {th }}$ and $60^{\text {th }}$ percentiles \\
\hline HighDroughts & Equals one for firms having Droughts above the $60^{\text {th }}$ percentile, 0 for firms below the $40^{\text {th }}$ percentile. Set to missing between the $40^{\text {th }}$ and $60^{\text {th }}$ percentiles \\
\hline HighHeatwaves & Equals one for firms having Heat waves above the $60^{\text {th }}$ percentile, 0 for firms below the $40^{\text {th }}$ percentile. Set to missing between the $40^{\text {th }}$ and $60^{\text {th }}$ percentiles \\
\hline HighHeavyrainfall & Equals one for firms having Heavy rainfall above the $60^{\text {th }}$ percentile, 0 for firms below the $40^{\text {th }}$ percentile. Set to missing between the $40^{\text {th }}$ and $60^{\text {th }}$ percentiles \\
\hline HighRainfallpatterns & Equals one for firms having Rainfall patterns above the $60^{\text {th }}$ percentile, 0 for firms below the $40^{\text {th }}$ percentile. Set to missing between the $40^{\text {th }}$ and $60^{\text {th }}$ percentiles \\
\hline HighSealevelrise & Equals one for firms having Sea level rise above the $60^{\text {th }}$ percentile, 0 for firms below the $40^{\text {th }}$ percentile. Set to missing between the $40^{\text {th }}$ and $60^{\text {th }}$ percentiles \\
\hline HighStorms & Equals one for firms having Storms above the $60^{\text {th }}$ percentile, 0 for firms below the $40^{\text {th }}$ percentile. Set to missing between the $40^{\text {th }}$ and $60^{\text {th }}$ percentiles \\
\hline HighTemperaturerise & Equals one for firms having Temperature rise above the $60^{\text {th }}$ percentile, 0 for firms below the $40^{\text {th }}$ percentile. Set to missing between the $40^{\text {th }}$ and $60^{\text {th }}$ percentiles \\
\hline Log Age & $\begin{array}{l}\text { Natural logarithm of the difference between the year of observation and the initial public offering year (using IPODATE in Compustat). If the Names file }{ }^{1} \text { indicates } \\
\text { a higher age, we substitute the Names file number to our previous measure }\end{array}$ \\
\hline Log Amount & $\begin{array}{l}\text { Natural logarithm of the amount borrowed, expressed in US dollars. Corresponds to Amount Issued (USD) in Thomson-Reuters and to Facility Amount multiplied } \\
\text { by Exchange Rate in Dealscan }\end{array}$ \\
\hline Log IntCoverage & Natural logarithm of the ratio of EBIT to interest expenses. EBIT/XINT in Compustat \\
\hline Log Maturity & $\begin{array}{l}\text { Natural logarithm of the maturity expressed in months. Corresponds to the number of months between issue date and maturity in Thomson-Reuters, and between } \\
\text { start date and end date in Dealscan }\end{array}$ \\
\hline Log Spread & $\begin{array}{l}\text { For bonds: natural logarithm of benchmark yield at issue in Bloomberg. For bank loans: natural logarithm of Bps, in Dealscan. If the spread is expressed with } \\
\text { respect to several benchmarks, we use the LIBOR-based measure }\end{array}$ \\
\hline Log TotAssets & $\begin{array}{l}\text { Natural logarithm of book assets (AT in Compustat). Book asset amounts are converted to US dollars using the year-end exchange rates from the OECD data } \\
\text { portal }^{2}\end{array}$ \\
\hline MarketLev & $\begin{array}{l}\text { Long-term debt divided by the sum of the year-end market capitalization and the difference between book asset value and common/ordinary equity. } \\
\text { DLTT/(AT-CEQ+PRCC_F*CSHO) in Compustat North America, } \\
\text { DLTT/(AT-CEQ+PRCCD*CSHOC) in Compustat Global }\end{array}$ \\
\hline No CreditRating & Equals one if CreditRating is null and zero otherwise \\
\hline OpEx & Ratio of operational expenses to book assets. XOPR/AT in Compustat \\
\hline Overall CSR Score & IVA Company Rating given in MSCI IVA ratings, converted from 0 for the worst grade (CCC) to 6 for the best grade (AAA) \\
\hline Post2015 & Equals one for observations after 2015 and zero otherwise \\
\hline PPE & Ratio of net tangible assets to book assets. PPENT/AT in Compustat \\
\hline Rainfall patterns & CRIS rainfall pattern risk grade for median scenario, 2050 time-horizon. Source Carbone 4, March 2018. \\
\hline R\&DExp & Ratio of R\&D expenses to book assets. XRD/AT in Compustat \\
\hline Sea level rise & CRIS sea level rise risk grade for median scenario, 2050 time-horizon. Source Carbone 4, March 2018. \\
\hline Storms & CRIS storm risk grade for median scenario, 2050 time-horizon. Source Carbone 4, March 2018. \\
\hline Temperature rise & CRIS rise in average temperature risk grade for median scenario, 2050 time-horizon. Source Carbone 4, March 2018. \\
\hline TobinQ & $\begin{array}{l}\text { Ratio of the sum of the year-end market capitalization and the difference between book asset value and common/ordinary equity, to book asset value. (AT- } \\
\text { CEQ+PRCC_F*CSHO)/AT in Compustat North America, (AT-CEQ+PRCCD*CSHOC)/AT in Compustat Global }\end{array}$ \\
\hline Upgrade & Equals one if CreditRating is higher than the lagged value of CreditRating. Set to missing if CreditRating or its lagged value are missing \\
\hline WorkingCap & Ratio of working capital to book assets. WCAP/AT in Compustat \\
\hline
\end{tabular}

${ }^{1}$ https://wrds-web.wharton.upenn.edu/wrds/tools/variable.cfm?library id=129\&file id=65815

2 https://data.oecd.org/conversion/exchange-rates.htm 


\section{Appendix B. Credit rating linearization}

\begin{tabular}{llll}
\hline S\&P Rating & Moody's Rating & Fitch Rating & Linear value \\
\hline AAA & Aaa & AAA & 20 \\
AA+ & Aa1 & AA+ & 19 \\
AA & Aa2 & AA & 18 \\
AA- & Aa3 & AA- & 17 \\
A+ & A1 & A+ & 16 \\
A & A2 & A & 15 \\
A- & A3 & A- & 14 \\
BBB+ & Baa1 & BBB+ \\
BBB & Baa2 & BBB & 13 \\
BBB- & Baa3 & BBB- & 12 \\
BB+ & Ba1 & BB+ & 11 \\
BB & Ba2 & BB & 10 \\
BB- & Ba3 & BB- & 9 \\
B+ & B1 & B+ & 8 \\
B & B2 & B & 7 \\
B- & B3 & B- & 6 \\
CCC+ & Caa1 & CCC+ \\
CCC & Caa2 & CCC & 5 \\
CCC- & Caa3 & CCC- & 4 \\
CC & Ca & CC & 4 \\
C & D & C & 4 \\
RD & & DDD & DD \\
SD & & D & 1 \\
D & & & 1 \\
\hline
\end{tabular}

